Research papers

\title{
Diagnostic modeling of dimethylsulfide production in coastal water west of the Antarctic Peninsula
}

\author{
Maria Herrmann ${ }^{\mathrm{a}, *}$, Raymond G. Najjar ${ }^{\mathrm{a}}$, Aimee R. Neeley ${ }^{\mathrm{b}}$, Maria Vila-Costa ${ }^{\mathrm{c}}$, John W.H. Dacey ${ }^{\mathrm{d}}$, \\ Giacomo R. DiTullio ${ }^{\mathrm{e}}$, David J. Kieber ${ }^{\mathrm{f}}$, Ronald P. Kiene ${ }^{\mathrm{g}}$, Patricia A. Matrai ${ }^{\mathrm{h}}$, Rafel Simó ${ }^{\mathrm{i}}$, Maria Vernet $^{\mathrm{j}}$ \\ a Department of Meteorology, The Pennsylvania State University, 503 Walker Building, University Park, PA 16802, USA \\ b NASA Goddard Space Flight Center, Ocean Ecology Branch, USA \\ ${ }^{\mathrm{c}}$ Group of Limnology, Department of Continental Ecology, Centre d'Estudis Avançats de Blanes_CSIC, Blanes, Catalunya, Spain \\ d Department of Biology, Woods Hole Oceanographic Institution, Woods Hole, MA 02543, USA \\ e Grice Marine Laboratory, University of Charleston, 205 Fort Johnson, Charleston, SC 29412, USA \\ ${ }^{\mathrm{f}}$ Department of Chemistry, State University of New York, College of Environmental Science and Forestry, One Forestry Drive, Syracuse, NY 132010, USA \\ ${ }^{\mathrm{g}}$ Dauphin Island Sea Laboratory, University of South Alabama, 101 Bienville Boulevard, Dauphin Island, AL 36528, USA \\ ${ }^{\mathrm{h}}$ Bigelow Laboratory for Ocean Sciences, 180 McKown Point, P.O. Box 475, West Boothbay Harbor, ME 04575, USA \\ ${ }^{\mathrm{i}}$ Institut de Ciències del Mar, CSIC, Pg Marítim de la Barceloneta 37-49, 08003 Barcelona, Spain \\ ${ }^{\mathrm{j}}$ Integrative Oceanography Division, Mail Code 0218, Scripps Institution of Oceanography, University of California San Diego, 9500 Gilman Drive, La Jolla, CA 92093, USA
}

\section{A R T I C L E I N F O}

\section{Article history:}

Received 30 April 2011

Received in revised form

22 October 2011

Accepted 25 October 2011

Available online 12 November 2011

\section{Keywords:}

Dimethylsulfide

DMS

Dimethylsulfoniopropionate

DMSP

Antarctic Peninsula

Palmer Station

\begin{abstract}
A B S T R A C T
The rate of gross biological dimethylsulfide (DMS) production at two coastal sites west of the Antarctic Peninsula, off Anvers Island, near Palmer Station, was estimated using a diagnostic approach that combined field measurements from 1 January 2006 through 1 March 2006 and a one-dimensional physical model of ocean mixing. The average DMS production rate in the upper water column $(0-60 \mathrm{~m})$ was estimated to be $3.1 \pm 0.6 \mathrm{nM} \mathrm{d}^{-1}$ at station B (closer to shore) and $2.7 \pm 0.6 \mathrm{nM} \mathrm{d}^{-1}$ at station E (further from shore). The estimated DMS replacement time was on the order of $1 \mathrm{~d}$ at both stations. DMS production was greater in the mixed layer than it was below the mixed layer. The average DMS production normalized to chlorophyll was $0.5 \pm 0.1\left(\mathrm{nM} \mathrm{d}^{-1}\right) /\left(\mathrm{mg} \mathrm{m}^{-3}\right)$ at station $B$ and $0.7 \pm 0.2\left(\mathrm{nM} \mathrm{d}^{-1}\right) /\left(\mathrm{mg} \mathrm{m}^{-3}\right)$ at station $\mathrm{E}$. When the diagnosed production rates were normalized to the observed concentrations of total dimethylsulfoniopropionate (DMSPt, the biogenic precursor of DMS), we found a remarkable similarity between our estimates at stations $B$ and $E(0.06 \pm 0.02$ and $0.04 \pm 0.01\left(\mathrm{nM} \mathrm{DMS} \mathrm{d}{ }^{-1}\right) /(\mathrm{nM}$ DMSP), respectively) and the results obtained in a previous study from a contrasting biogeochemical environment in the North Atlantic subtropical gyre $(0.047 \pm 0.006$ and $0.087 \pm 0.014$ (nM DMS d $\left.{ }^{-1}\right) /(\mathrm{nM}$ DMSP) in a cyclonic and anticyclonic eddy, respectively). We propose that gross biological DMS production normalized to DMSPt might be relatively independent of the biogeochemical environment, and place our average estimate at $0.06 \pm 0.01\left(\mathrm{nM} \mathrm{DMS} \mathrm{d} \mathrm{d}^{-1}\right) /(\mathrm{nM}$ DMSPt). The significance of this finding is that it can provide a means to use DMSPt measurements to extrapolate gross biological DMS production, which is extremely difficult to measure experimentally under realistic in situ conditions.
\end{abstract}

(c) 2011 Elsevier Ltd. All rights reserved.

\section{Introduction}

Dimethylsulfide (DMS) is a climate-relevant gas produced in the marine food web from the phytoplankton-derived precursor dimethylsulfoniopropionate (DMSP). Compelling observational and modeling evidence suggests that oceanic DMS emissions are

\footnotetext{
* Corresponding author. Tel.: +1570660 3535 .

E-mail addresses: mxh367@psu.edu (M. Herrmann), najjar@meteo.psu.edu (R.G. Najjar), phytogirl79@comcast.net (A.R. Neeley), mariavila@ceab.csic.es (M. Vila-Costa), jdacey@whoi.edu (J.W.H. Dacey), ditullioj@cofc.edu (G.R. DiTullio), djkieber@esf.edu (D.J. Kieber), rkiene@disl.org (R.P. Kiene), pmatrai@bigelow.org (P.A. Matrai), rsimo@icm.csic.es (R. Simó), mvernet@ucsd.edu (M. Vernet).
}

the largest biogenic source of sulfur to the atmosphere (Kettle and Andreae, 2000; Lana et al., 2011). DMS-derived aerosols influence the global radiation budget directly by scattering incoming photons and indirectly by acting as cloud condensation nuclei, thus increasing cloud albedo (Charlson et al., 1987; Ayers and Gillett, 2000; Leck and Bigg, 2010). DMS-derived aerosols are particularly important in the Antarctic region, due to high DMS concentrations in the surface waters during the austral spring and summer, coupled with low aerosol concentrations in the Antarctic troposphere, remote from terrestrial aerosol sources (Vallina et al., 2006). DMS is highly reactive in the atmosphere and has a short lifetime; consequently, atmospheric DMS concentrations are strongly influenced by local DMS emissions from the ocean. Ocean-atmosphere DMS fluxes, in turn, depend on the 
sea-surface DMS concentrations, which are controlled by biological processes involving the entire marine food web, as well as physical and chemical processes in the water column. One of the central problems in quantifying and modeling the DMS-climate connection is the lack of understanding of the dynamics of the marine DMS cycle in the upper water column (Simó, 2001). In particular, the most fundamental quantity in the budget - DMS production - is poorly constrained, due to the difficulties associated with direct experimental measurement under realistic in situ conditions.

To a first approximation, marine DMS is produced by algal and bacterial cleavage of DMSP released directly by phytoplankton or via viral and grazing activity (Gabric et al., 2001; Stefels et al., 2007). Apart from enzymatic DMSP cleavage, the only known production pathways for DMS are the enzymatic reduction of dimethylsulfoxide (DMSO; Spiese et al., 2009) and oxidation of DMSP by the hydroxyl radical (D.J. Kieber, unpublished results). The latter two processes are proposed to be the main source of DMS in marine algae that contain DMSP but do not contain measureable levels of DMSP lyase activity. However, it is not known how important these processes are as a source of dissolved DMS in the water column.

Production of DMS and DMSP by algae has various biological functions. DMSP is proposed to regulate osmotic pressure in the cells (Vairavamurthy et al., 1985) and to aid in cold tolerance (Kirst et al., 1991); DMSP and DMS may also act as infochemicals (Seymour et al., 2010) and be a part of an antioxidant mechanism (Sunda et al., 2002), or an overflow mechanism for excess reducing power (Stefels, 2000). The production of DMS by bacteria can be influenced by their need to assimilate sulfur from DMSP, which can divert sulfur away from DMS production (Howard et al., 2006; Simó et al., 2009). DMS loss processes include biological consumption by bacteria, photochemical oxidation, and removal from the ocean surface by ventilation to the atmosphere (Kiene and Bates, 1990; Kieber et al., 1996; del Valle et al., 2009). While robust approaches have been developed to measure microbial and photochemical removal of DMS from the water column, direct measurement of the biological production of DMS under in situ conditions is difficult because of the multiple ways by which DMS can be produced, including intracellular, extracellular, viral, and grazing-related mechanisms, and also the fact that the natural light field can affect DMS production (Slezak et al., 2007; Galí et al., 2011).

Toole and Siegel (2004) proposed two regimes of the pelagic ecosystem for DMS cycling: a stress regime and a bloom regime. The bloom regime refers to highly productive ocean regions, where the highest DMS concentrations are observed during a peak in primary production and chlorophyll $a(C h l)$, which is often used as a proxy for phytoplankton biomass. The stress regime describes conditions when DMS and Chl are decoupled, and DMS production occurs in response to oxidative stress, as proposed by Sunda et al. (2002). Such conditions exist, for example, in the subtropical gyres, where low nutrient content and high solar radiation exert considerable physiological stress on marine organisms within the mixed layer. Bailey et al. (2008) conducted a diagnostic DMS study in the western part of the North Atlantic subtropical gyre (the Sargasso Sea), corresponding to a stress DMS regime. In contrast, the present study addressed DMS production in a highly productive coastal environment of the Southern Ocean, which we hypothesize represents a bloom DMS regime, where DMS production is closely correlated to Chl and DMSP concentrations.

The goal of the present study was to provide a quantitative estimate of gross biological DMS production in the coastal environment west of the Antarctic Peninsula using in situ estimates of chemical and biological DMS losses and the observed variability in DMS concentrations and related tracers. Gross biological DMS production is a fundamental quantity in the marine DMS budget that must be well constrained in order to improve our understanding of DMS-climate feedbacks and their representation in future climate modeling efforts. The difficulties associated with experimental measurement of DMS production motivated the need for indirect estimation of gross production flux from more easily measured quantities. We combined watercolumn measurements collected during the DMS field campaign and a physical model of ocean mixing into a diagnostic calculation of DMS production, which relied on the difference between the observed and modeled DMS concentrations to infer the gross biological DMS production rate in the water column.

\section{Methods}

\subsection{Study area}

The study area was located in the coastal waters of the Southern Ocean, to the west of the Antarctic Peninsula, off Anvers Island, near Palmer Station $\left(64.77^{\circ} \mathrm{S}, 64.055^{\circ} \mathrm{W}\right)$. We focused on two stations located near the inlet to Palmer Station, B $\left(64.78^{\circ} \mathrm{S}\right.$, $\left.64.075^{\circ} \mathrm{W}\right)$ and $\mathrm{E}\left(64.82^{\circ} \mathrm{S}, 64.041^{\circ} \mathrm{W}\right)$, which are routinely sampled as part of the Long Term Ecological Research (LTER) program (Fig. 1). The LTER program has continuously operated a sampling network in the vicinity of Palmer Station for nearly 20 years, starting in 1990 (http://pal.lternet.edu), providing valuable ancillary data to our study. The total water column depth is $\sim 80 \mathrm{~m}$ at station $\mathrm{B}$ and $\sim 172 \mathrm{~m}$ at station $\mathrm{E}$. These near-shore stations are affected by melt-water and runoff from the glaciers on Anvers Island and other small islands in the vicinity (Dierssen et al., 2002). Station B is located closer to the coast and the glacial melt-water source. Historical LTER data, available online, indicate that station B is characterized by lower water temperatures and salinities, higher Chl concentrations, and greater nutrient drawdown during the austral summer, compared with station E. Both stations experience warming and freshening of the water column during the austral summer but seasonal warming at station B is less pronounced than at station E, likely due to the glacial meltwater influx. A signal of deep intrusion of high-salinity oceanic water is evident at both stations, but is more pronounced at the deeper station $\mathrm{E}$.

\subsection{Field measurements}

The DMS field campaign was coordinated with the LTER 20052006 summer sampling program and took place between November 2005 and February 2006. Routine LTER sampling was conducted from a zodiac boat, approximately every $2-3 \mathrm{~d}$, weather and sea-ice conditions permitting. Conductivity-temperature-depth (CTD) measurements were collected with a SeaBird SBE 19 SEACAT instrument and processed with the SeaBird software to produce temperature $(T)$ and salinity $(S)$ profiles at 1-m resolution. Underwater irradiance profiles were measured with a BSI PRR-800 Profiling Reflectance Radiometer at 16 wavelengths (Chang and Dickey, 2004). Discrete water samples were analyzed for Chl by fluorometry (Holm-Hansen et al., 1965) and for nitrate $(N)$ by colorimetric spectroscopy (Knap et al., 1994). From November to February, in addition to routine LTER sampling, water samples were collected from approximately 6 depths for DMS and DMSP analyses. Dissolved DMS and total DMSP (DMSPt) concentrations were determined with a Shimadzu GC-14 gas chromatograph according to the procedure described in Kiene and Service (1991). In January and February, microbial consumption rate constants for DMS were determined with ${ }^{35} \mathrm{~S}$ tracer methods (Kiene and Linn, 2000; del Valle et al., 2009). Incubations were done in the 


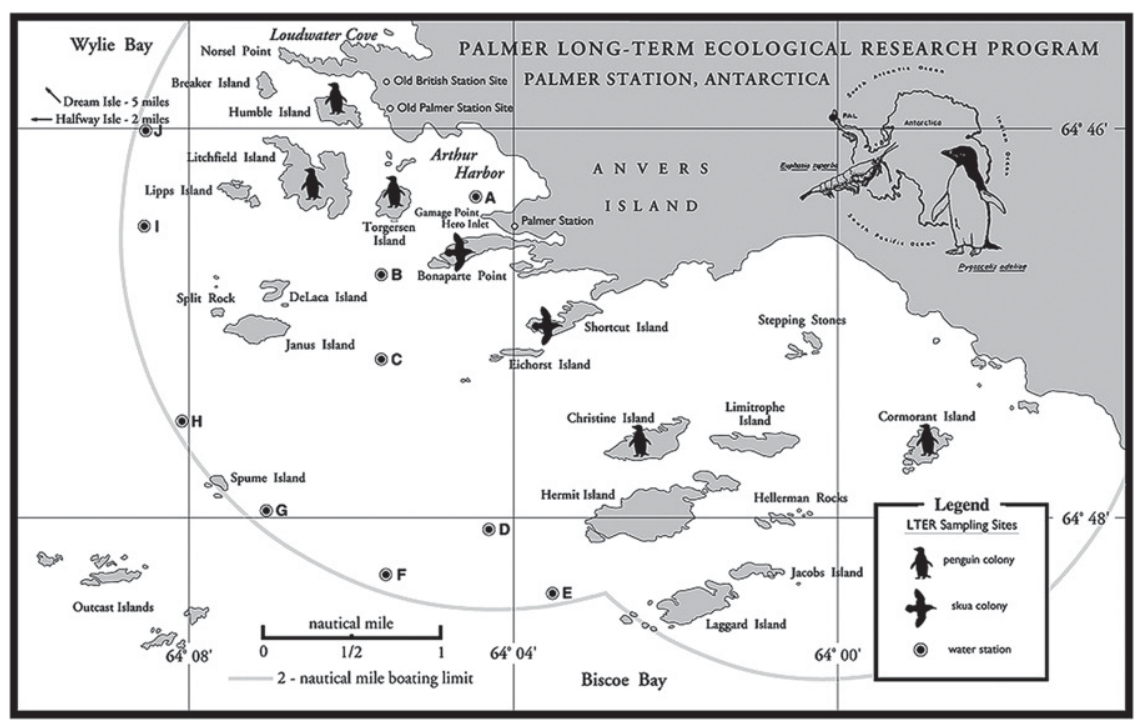

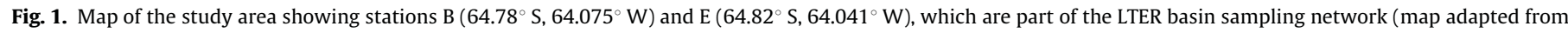
LTER Palmer website http://pal.lternet.edu/sci-research/sampling-grid/).

dark and thus our method does not take into account the effects of light on microbial DMS consumption, i.e., mainly inhibition due to UV radiation (Toole et al., 2006). Absorption coefficients of chromophoric dissolved organic matter (CDOM) and apparent quantum yields for DMS photolysis were measured in order to determine photolysis rate constants (Toole et al., 2003; Bailey et al., 2008). CDOM absorption coefficients were determined for the wavelength range from $210 \mathrm{~nm}$ to $750 \mathrm{~nm}$ using a Hewlett Packard 8453 UV-vis photodiode array spectrophotometer. Wavelength-dependent quantum yields were determined employing a polychromatic approach outlined in Toole et al. (2003), using $0.2 \mu \mathrm{m}$-filtered sea water samples, collected on 24 January 2006. Photochemical DMS loss was quantified using the ${ }^{35}$ S tracer method (Toole et al., 2004), and the UV-B (290-320 nm) and UV-A (320-400 $\mathrm{nm}$ ) photon fluxes were determined by chemical actinometry (Kieber et al., 2007). Photolysis results were scaled to 1-nM DMS concentration to produce spectral apparent quantum yields, i.e., moles of DMS lost per mole of photons absorbed by CDOM in a 1-nM DMS solution (Toole et al., 2003).

For this study, we focused on the period from 1 January to 1 March of 2006, when sampling frequency was the highest due to favorable weather conditions and all DMS-related measurements needed to constrain the DMS budget were performed concurrently. The field measurements were linearly interpolated to a regular time and depth grid for all the following analyses.

\subsection{Diagnostic calculations}

To estimate gross biological DMS production flux from the available field measurements, we performed a diagnostic modeling exercise based on the Reynolds-averaged statement of tracer conservation in turbulent flow (Holton, 1992). Conceptually, the average tracer concentration at any location in the flow is controlled by physical processes of advection and turbulent diffusion (mixing), and by sources and sinks of biogeochemical origin. Therefore, a three-dimensional conservation equation for any tracer can be formulated as follows:

$\frac{\partial C}{\partial t}=-U_{i} \frac{\partial C}{\partial x_{i}}-\frac{\partial}{\partial x_{i}}\left(\overline{u_{i} C}\right)+J \quad(i=1,2,3)$ where $C$ is the mean component of tracer concentration, $c$ is the fluctuating component of tracer concentration, $U_{i}$ is the mean velocity component of the flow, $u_{i}$ is the fluctuating component of the flow, and $J$ is an unconstrained biogeochemical term. A quantitative estimate of the unknown biogeochemical processes can be diagnosed if all terms are constrained with observations and theory, except for $J$, which is treated as the only unknown. The underlying motivation behind the indirect approach to quantify tracer fluxes from tracer concentration data is that direct measurements of oceanic fluxes are difficult to make and, as a consequence, flux data are prone to large measurement errors. In comparison, tracer concentration measurements are generally more reliable and have a broader spatial and temporal coverage. In addition, the theory describing the physical processes is more advanced compared with the theory behind prognostic biogeochemical modeling. While the diagnostic approach is straightforward conceptually, it becomes challenging in practical application because uncertainties in the diagnosed source terms are strongly dependent on the quality of the physical simulations and on the availability and quality of the data used to constrain the temporal and spatial tracer gradients.

\subsubsection{General model configuration}

To quantify the DMS budget at LTER stations B and E, we reformulated the one-dimensional form of Eq. (1) as

$\frac{\partial C}{\partial t}=J_{\text {mix }}+J_{\text {mic }}+J_{\text {phot }}+J_{\text {prod }}$,

where $C[\mathrm{nM}]$ is the DMS concentration, $J_{\text {mix }}\left[\mathrm{nM} \mathrm{s}^{-1}\right]$ represents the rate of DMS gain or loss due to turbulent mixing, and the biogeochemical term, $J$, is separated into three components: the rate of microbial consumption, $J_{\text {mic }}\left[\mathrm{nM} \mathrm{s}^{-1}\right]$; the rate of photochemical oxidation, $J_{\text {phot }}\left[\mathrm{nM} \mathrm{s}^{-1}\right]$; and the rate of gross biological production, $J_{\text {prod }}\left[\mathrm{nM} \mathrm{s}^{-1}\right]$, which is the objective of the diagnostic calculations. Atmospheric ventilation was included into the mixing term as a surface boundary condition. Horizontal advection was assumed negligible compared to the other terms in Eq. (2) (see Sections 3.1 and 3.2).

For numerical implementation, we embedded a DMS module into the framework of the General Ocean Turbulence Model (GOTM), which is a one-dimensional physical model that, given the surface forcing, simulates vertical mixing in the water column 
and solves the one-dimensional transport equations for momentum, salt, and heat energy. The model is described in Burchard et al. (1999) and a complete GOTM documentation is available online at http://gotm.net.

The model domain depth was set to $60 \mathrm{~m}$, with depth resolution of $2 \mathrm{~m}$, and the positive $z$ coordinate was directed upward. The model was initialized with observed profiles of $T, S$, and DMS, and integrated from 1 January 2006 (Julian day 1) through 1 March 2006 (Julian day 60) using a 30-min time step (chosen to ensure numerical stability of the physical simulation), with the biological production term excluded from the DMS budget. At each time step, gross biological production at a given depth was diagnosed from the difference between observed and modeled DMS concentrations:

$J_{\text {prod }}(t, z)=\frac{C_{o b s}(t, z)-C_{\text {mod }}(t, z)}{\Delta t}$,

where $C_{\bmod }[\mathrm{nM}]$ is the DMS concentration calculated by the model, $C_{o b s}[\mathrm{nM}]$ is the DMS concentration produced by linearly interpolating measured DMS concentration profiles to the model vertical and temporal grid, and $\Delta t[\mathrm{~s}]$ is the model time step. Following each diagnostic calculation at a given time step, model DMS concentrations were restored to observations at that time step before proceeding to the next model iteration. The model depth and time domains were selected based on the availability of observational data and excluded November and December of 2005, when sampling was sparse due to adverse sea-ice conditions. The specific treatment of each rate term in Eq. (2) is discussed in the following sections.

\subsubsection{Rate of turbulent mixing}

The rate of vertical mixing was modeled in terms of the turbulent eddy diffusivity:

$J_{\text {mix }}(t, z)=\frac{\partial}{\partial z}(\overline{w C})=\frac{\partial}{\partial z}\left(v(t, z) \frac{\partial C(t, z)}{\partial z}\right)$,

where $\overline{w c}\left[\mathrm{nM} \mathrm{m} \mathrm{s}^{-1}\right]$ is the vertical turbulent flux of DMS, and $v\left[\mathrm{~m}^{2} \mathrm{~s}^{-1}\right]$ is the vertical eddy diffusivity. In all base-run calculations, we used the $K$ profile parameterization (KPP) turbulence closure of Large et al. (1994) to determine the vertical eddy diffusivity. In the error analysis calculations described in Section 2.3.7, we used the $k-\varepsilon$ turbulence closure of Rodi (1987).

\subsubsection{Rate of gas exchange}

The air-sea DMS flux due to gas exchange, $F_{\text {gas }}\left[\mathrm{nM} \mathrm{m} \mathrm{s}{ }^{-1}\right.$ ], was included into the mixing term in the surface grid box and acted as a surface boundary condition:

$-v(t, z=0) \frac{\partial C(t, z=0)}{\partial z}=F_{\text {gas }}(t)$.

For gas flux calculations, we used the stagnant film model, in which, following Kettle and Andreae (2000), we assumed that equilibrium ocean surface DMS concentrations were negligibly small compared to actual surface ocean concentrations:

$F_{\text {gas }}(t)=k_{w}(t) C(t, z=0)$,

where $k_{w}\left[\mathrm{~m} \mathrm{~s}^{-1}\right]$ is the gas transfer velocity for DMS. To parameterize $k_{w}$ we used the formulation of Wanninkhof (1992):

$k_{w}=\gamma U_{10}^{2}(S c / 600)^{-0.5}$,

where $\gamma=0.31\left(\mathrm{~cm} \mathrm{~h}^{-1}\right) /\left(\mathrm{m}^{2} \mathrm{~s}^{-2}\right)$ is an empirical constant, $U_{10}$ $\left[\mathrm{m} \mathrm{s}^{-1}\right]$ is the 30 -min averaged wind speed at $10 \mathrm{~m}$ above sea surface, and $S c$ is the dimensionless Schmidt number. The relationship gives $k_{w}$ in units of $\mathrm{cm} \mathrm{h}^{-1}$. In the error analysis calculations (see Section 2.3.7), we used a wide uncertainty range for $k_{w}$ in order to encompass the spread of other available gas transfer velocity parameterizations (Liss and Merlivat, 1986;
Nightingale et al., 2000; Blomquist et al., 2006; Vlahos and Monahan, 2009). The Schmidt number for DMS was calculated from sea-surface $T$ according to the polynomial fit of Saltzman et al. (1993), and the wind speed observations were obtained from the automated weather system located at Palmer Station (Section 2.3.6).

\subsubsection{Rate of microbial DMS consumption}

The rate of microbial DMS consumption was modeled as a first-order process with the rate constant, $k_{\text {mic }}\left[\mathrm{s}^{-1}\right]$, constrained by in situ measurements that were linearly interpolated to match the model depth and time grid:

$J_{\text {mic }}(t, z)=-k_{\text {mic }}(t, z) C(t, z)$.

When vertical interpolation was required, we assumed that $k_{\text {mic }}$ was equal to zero at $100 \mathrm{~m}$, with the rationale that as DMS concentrations approached zero at that depth, microbial consumption of DMS could be assumed zero also and, consequently, setting $k_{\text {mic }}$ to zero was permissible for interpolation purposes.

\subsubsection{Rate of DMS photolysis}

Photochemical oxidation was modeled as a first-order process dependent on the photolysis rate constant, $k_{\text {phot }}\left[\mathrm{s}^{-1}\right]$ :

$J_{\text {phot }}(t, z)=-k_{\text {phot }}(t, z) C(t, z)$.

The photolysis rate constant was determined using the algorithm of Toole et al. (2003):

$k_{\text {phot }}(t, z)=\int_{\lambda_{1}}^{\lambda_{2}} a_{C D O M}(\lambda, t) E_{0}(\lambda, t, z) \Phi(\lambda) d \lambda$,

where $\lambda[\mathrm{nm}]$ is the wavelength, $a_{C D O M}\left[\mathrm{~m}^{-1}\right]$ is the CDOM absorption coefficient, $E_{0}\left[\mathrm{E} \mathrm{m}^{-2} \mathrm{~s}^{-1} \mathrm{~nm}^{-1}\right]$ is the scalar irradiance, and $\Phi\left[\mathrm{m}^{3} \mathrm{E}^{-1}\right]$ is the apparent quantum yield (moles of DMS lost per one mole of photons absorbed by CDOM, normalized to DMS concentration). It should be noted that a non-SI unit, einstein [E], was used to represent one mole of photons. The integration limits were $\lambda_{1}=290 \mathrm{~nm}$ and $\lambda_{2}=600 \mathrm{~nm}$. CDOM absorption coefficients and quantum yields were determined on the basis of field measurements at each station. Wavelengthdependent quantum yields from the measurements were fit with an exponential relationship, which was then used to calculate $\Phi(\lambda)$ at the required wavelength resolution. Similarly, at each measurement time, surface wavelength-dependent $a_{C D O M}$ spectra were fit with an exponential function. The fit coefficients were then linearly interpolated in time to produce $a_{C D O M}(\lambda, t)$ fields of required temporal resolution. Following Toole et al. (2003), $E_{0}$ irradiance was set to $1.2 E_{d}$ (after accounting for unit conversion):

$E_{0}=\frac{1.2 E_{d}}{h v N_{A}}$,

where $E_{d}\left[\mathrm{~W} \mathrm{~m} \mathrm{~m}^{-2} \mathrm{~nm}^{-1}\right]$ is the measured downwellling spectral irradiance, $h=6.6262 \times 10^{-34}[\mathrm{~J} \mathrm{~s}]$ is Plank's constant, $v\left[\mathrm{~s}^{-1}\right]$ is the frequency, and $N_{A}=6.022 \times 10^{23}\left[\mathrm{~mol}^{-1}\right]$ is Avogadro's number. To compute the downwelling underwater spectral irradiance fields at the 30 -min resolution required by the diagnostic model, we combined the surface downwelling spectral irradiance measurements of high temporal resolution (from the spectral pyranometer at Palmer Station, see Section 2.3.6) and the spectral attenuation coefficients $K_{d}\left[\mathrm{~m}^{-1}\right]$, calculated by fitting exponential decay curves to the measured spectral underwater irradiance profiles of lower temporal resolution (see Section 2.2):

$E_{d}(\lambda, t, z)=\beta E_{d}(\lambda, t, 0) \exp \left[K_{d}(\lambda) z\right]$,

where $\beta=0.96$ is the wavelength-independent light transmission across the air-sea interface, following Bailey et al. (2008). 

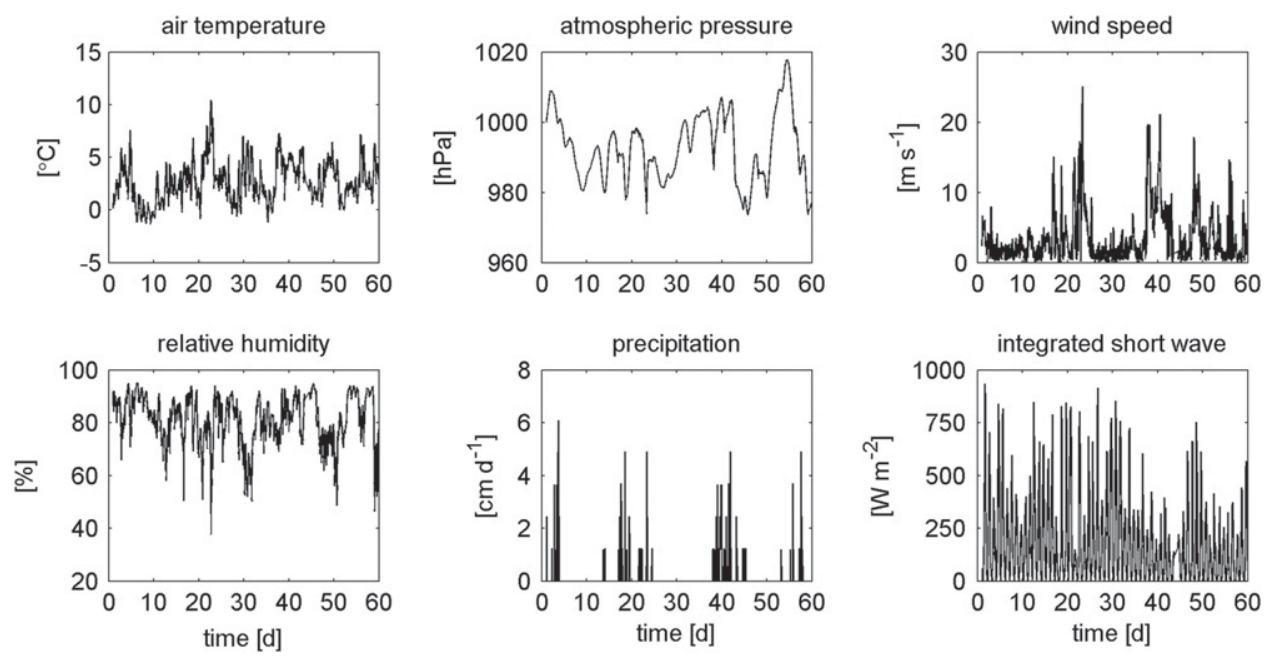

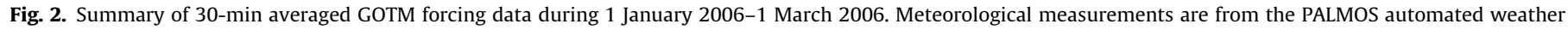
system located at Palmer Station. Integrated shortwave irradiance measurements are from a spectral pyranometer located at Palmer Station.

Table 1

Summary of error-estimation runs and errors assigned to each input variable.

\begin{tabular}{|c|c|c|c|}
\hline Model run number & Altered input variable & Method of error assignment & Source \\
\hline$R 1$ & $C[\mathrm{nM}]$ & Fractional error $= \pm 10 \%$ & $\begin{array}{l}\text { Estimated from reported DMS } \\
\text { measurement errors }\end{array}$ \\
\hline$R 2$ & $v\left[\mathrm{~m}^{2} \mathrm{~s}^{-1}\right]$ & $\begin{array}{l}\text { Used alternative turbulence closure } \\
\text { scheme }\end{array}$ & $\begin{array}{l}\text { Subjective selection of Rodi (1987) } \\
\text { turbulence model }\end{array}$ \\
\hline$R 3$ & $k_{w}\left[\mathrm{~m} \mathrm{~s}^{-1}\right]$ & $\begin{array}{l}\text { Fractional error }= \pm 50 \% \text { assigned to } \\
\text { empirical } \gamma \text { coefficient in the } \\
\text { Wanninkhof }(1992) \text { formulation }\end{array}$ & Subjective estimate \\
\hline$R 4$ & $k_{\text {mic }}\left[\mathrm{s}^{-1}\right]$ & Fractional error $= \pm 16 \%$ & $\begin{array}{l}\text { Estimated from reported } \\
\text { measurement errors }\end{array}$ \\
\hline R5 & $k_{\text {phot }}\left[\mathrm{s}^{-1}\right]$ & Fractional error $= \pm 50 \%$ & Subjective estimate \\
\hline
\end{tabular}

\subsubsection{Model forcing}

The GOTM was forced with wind velocity, atmospheric temperature, pressure, humidity, precipitation, and downwelling shortwave radiation (Fig. 2). We used 30-min averaged atmospheric measurements from the PALMOS automated weather system located at Palmer Station and operated by the Antarctic Meteorological Research Center; data are available online at ftp://ice.ssec.wisc.edu/pub/palmer/observations. For downwelling shortwave radiation forcing, we used 30-min averaged integrated (0.285-2.8 $\mu \mathrm{m})$ solar radiation measured with an Eppley Laboratory Precision Spectral Pyranometer operated by Biospherical Instruments, Inc., at Palmer Station; data are available online at http://www.biospherical.com/nsf.

Given that GOTM is one-dimensional, all horizontal gradients must be prescribed outside the model if one were to include the horizontal advection process into the calculation. Because the spatial coverage of our field measurements was limited to only two stations, prescribing observed horizontal tracer gradients for GOTM was not feasible and we chose to use a simple nudging method to account for the horizontal advection of $T$ and $S$. The measured profiles of $T$ and $S$ were linearly interpolated to the model vertical and temporal grids and, at each time step, the model was relaxed towards the observations using a one-day relaxation time-scale, i.e., the following nudging source term was added to both $T$ and $S$ conservation equations:

$J_{\text {nudg }}=-\frac{1}{\tau}\left(Y_{\bmod }-Y_{o b s}\right)$ where $\tau$ is the nudging time scale and $Y$ represents $T$ or $S$. In addition to horizontal advection, the nudging term potentially corrects for other physical processes that might play a role in the modeled environment but are not explicitly resolved in the physical model, such as a glacial melt-water source (Dierssen et al., 2002) and any possible tidal influence.

\subsubsection{Processing of model outputs and error estimation}

All model outputs at the original 30-min and 2-m resolution were averaged daily and then all days were averaged between each two consecutive times when the water column was sampled. Averaged model outputs were used in all subsequent analyses and are referred to as model output in the following discussion.

To streamline analyses of the vertical structure, we divided the model water column into three equal-depth intervals: the $0-\mathrm{m}$ to 20 $\mathrm{m}$ interval is referred to as the surface interval (SFC) and approximately corresponds to the mixed layer; the $20-\mathrm{m}$ to $40-\mathrm{m}$ layer is referred to as the middle interval (MID); and the 40-m to 60-m layer is referred to as the bottom interval (BOT). The entire model water column, from $0 \mathrm{~m}$ to $60 \mathrm{~m}$, is referred to as the total column (TOT).

To provide a measure of significance of the final results, we selected a number of model input variables that we believed contributed appreciably to the final error in the model output. We assigned standard errors to these independent variables, combining available information about the measurement errors and our best judgment about the uncertainty in the model parameters (Table 1), 
Table 2

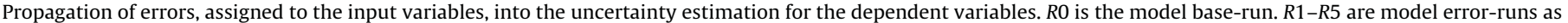
described in Table 1. Error notation follows Eq. (14).

\begin{tabular}{|c|c|c|c|}
\hline Dependent variable & Input variables & $\begin{array}{l}\text { Partial errors in the dependent variable } \\
\text { due to each input variable }\end{array}$ & $\begin{array}{l}\text { Combination of the partial errors into the total error in the } \\
\text { dependent variable }\end{array}$ \\
\hline \multirow[t]{2}{*}{$J_{\text {mix }}$} & $C$ & $\Delta J_{m i x}^{C}=J_{m i x, R 1}-J_{m i x, R 0}$ & \multirow[t]{2}{*}{$\left(\Delta J_{\text {mix }}\right)^{2}=\left(\Delta J_{\text {mix }}^{C}\right)^{2}+\left(\Delta J_{\text {mix }}^{v}\right)^{2}$} \\
\hline & $v$ & $\Delta J_{m i x}^{v}=J_{m i x, R 2}-J_{m i x, R 0}$ & \\
\hline \multirow[t]{2}{*}{$J_{\text {gas }}$} & $C$ & $\Delta J_{g a s}^{C}=J_{g a s, R 1}-J_{g a s, R 0}$ & \multirow[t]{2}{*}{$\left(\Delta J_{g a s}\right)^{2}=\left(\Delta J_{g a s}^{C}\right)^{2}+\left(\Delta J_{g a s}^{k_{w}}\right)^{2}$} \\
\hline & $k_{w}$ & $\Delta J_{g a s}^{k_{w}}=J_{g a s, R 3}-J_{g a s, R 0}$ & \\
\hline \multirow[t]{2}{*}{$J_{\text {mic }}$} & C & $\Delta J_{m i c}^{C}=J_{m i c, R 1}-J_{m i c, R 0}$ & \multirow[t]{2}{*}{$\left(\Delta J_{m i c}\right)^{2}=\left(\Delta J_{m i c}^{C}\right)^{2}+\left(\Delta J_{m i c}^{k_{m i c}}\right)^{2}$} \\
\hline & $k_{\text {mic }}$ & $\Delta J_{m i c}^{k_{m i c}}=J_{m i c, R 4}-J_{m i c, R 0}$ & \\
\hline \multirow[t]{2}{*}{$J_{\text {phot }}$} & C & $\Delta J_{\text {phot }}^{C}=J_{\text {phot }, R 1}-J_{\text {phot }, R 0}$ & \multirow[t]{2}{*}{$\left(\Delta J_{\text {phot }}\right)^{2}=\left(\Delta J_{\text {phot }}^{C}\right)^{2}+\left(\Delta J_{\text {phot }}^{k_{\text {phot }}}\right)^{2}$} \\
\hline & $k_{\text {phot }}$ & $\Delta J_{\text {phot }}^{k_{\text {phot }}}=J_{\text {phot }, R 4}-J_{\text {phot }, R 0}$ & \\
\hline \multirow[t]{5}{*}{$J_{\text {prod }}$} & $\mathrm{C}$ & $\Delta J_{\text {prod }}^{C}=J_{\text {prod,R1 }}-J_{\text {prod,R0 }}$ & \multirow[t]{5}{*}{$\left(\Delta J_{\text {prod }}\right)^{2}=\left(\Delta J_{\text {prod }}^{C}\right)^{2}+\left(\Delta J_{\text {prod }}^{v}\right)^{2}+\left(\Delta J_{\text {prod }}^{k_{w}}\right)^{2}+\left(\Delta J_{\text {prod }}^{k_{\text {mic }}}\right)^{2}+\left(\Delta J_{\text {prod }}^{k_{\text {plot }}}\right)^{2}$} \\
\hline & $v$ & $\Delta J_{\text {prod }}^{v}=J_{\text {prod, }, R 2}-J_{\text {prod,R0 }}$ & \\
\hline & $k_{w}$ & $\Delta J_{\text {prod }}^{k_{w}}=J_{\text {prod }, R 3}-J_{\text {prod, } R 0}$ & \\
\hline & $k_{\text {mic }}$ & $\Delta J_{\text {prod }}^{k_{\text {mic }}}=J_{\text {prod,R4 }}-J_{\text {prod,R0 }}$ & \\
\hline & $k_{\text {phot }}$ & $\Delta J_{\text {prod }}^{k_{\text {phot }}}=J_{\text {prod,R4 }}-J_{\text {prod,R0 }}$ & \\
\hline
\end{tabular}

and used a standard Taylor series expansion approach to propagate errors into the final results (Squires, 2001). For a general case of some variable $Z$ that is dependent on several input variables, $Z=Z(A, B, \ldots)$, the standard error in the dependent variable, $\Delta Z$, can be approximated from the known standard errors in the input variables, $\Delta A, \Delta B$, etc.: :

$(\Delta Z)^{2}=\left(\Delta Z^{A}\right)^{2}+\left(\Delta Z^{B}\right)^{2}+\cdots$,

where $\Delta Z^{A}=(\partial Z / \partial A) \Delta A$ is the change in the dependent variable when the input variable $A$ is changed by the amount of its standard error, holding the other input variables constant, and so on. The implicit assumption in Eq. (14) is that the error-contributing independent variables are uncorrelated so that their co-variances are negligible (Squires, 2001). We calculated the model output errors due to each error-contributing independent variable as the difference between the base-run $(R 0)$ and five error-runs $(R 1-R 5)$, in which the independent variables were altered, one at a time, as described in Table 1. Increasing or decreasing the input variables by the assigned amount resulted in approximately symmetric error in the output, that is, errors of approximately equal magnitude and opposite sign. A summary of the error propagation calculations is given in Table 2 .

\section{Results}

\subsection{Physical and biogeochemical characteristics}

Hydrographic observations for the modeling period are summarized in Fig. 3, with comparison between the two stations emphasized in the right-hand column. In Fig. 3 and all the following figures, the plotted error bars show one standard error of the means and are intended to allow visual comparison between the two stations. The mixed layer depth (MLD) was calculated as the depth at which the in situ $\sigma_{t}$ exceeded the seasurface $\sigma_{t}$ value by $0.125 \mathrm{~kg} \mathrm{~m}^{-3}$. The MLD criterion was selected subjectively from a range of tested criteria because it best represented the extent of surface mixing that was visually noticeable in the measured hydrographic and biogeochemical tracer fields.
The most pronounced feature emerging from this comparison was greater seasonal warming of the upper water column observed at station E, compared with station B. On average, the surface layer $(0-20 \mathrm{~m})$ at station B was slightly fresher compared with that at station E. These differences pointed to the influence of glacial meltwater at station B. Averaged over the total water column, the MLD was $\sim 10 \mathrm{~m}$ at station $B$ and varied between $10 \mathrm{~m}$ and $30 \mathrm{~m}$ at station E. Hydrographic differences between the stations were mostly confined to the upper $20 \mathrm{~m}$ of the water column.

Biogeochemical characteristics are summarized in Fig. 4, with comparison between the two stations shown in the right-hand column. For depth extrapolation, we assumed $0 \mathrm{nM}$ DMS and DMSPt concentrations, $0 \mathrm{mg} \mathrm{m}^{-3}$ Chl concentrations, and $30 \mu \mathrm{M}$ nitrate $(N)$ concentrations at $100-\mathrm{m}$ depth, which produced the best match with the deepest available profiles. Observed $\mathrm{Chl}$ concentrations were higher at station $B$ than at station $\mathrm{E}$ at all depth intervals, with the most pronounced difference observed in the upper $20 \mathrm{~m}$. Station B also had greater $N$ drawdown at the surface; however, as expected, $N$ concentrations remained relatively high even during the phytoplankton bloom. Based on the estimation of phytoplankton taxa using the CHEMTAX method (Kozlowski et al., 2011), phytoplankton species composition at both stations was mostly dominated by diatoms, with the exception of December, when cryptophytes dominated. The dominance of these two groups in the summer is consistent with the analysis of the 13-yr time series (1995-2007) on the shelf along the western Antarctic Peninsula (Kozlowski et al., 2011). DMSPt concentrations were clearly lower at station B compared with station $\mathrm{E}$ in the upper $20 \mathrm{~m}$ and were similar below $20 \mathrm{~m}$ depth. Averaged over the entire $60 \mathrm{~m}$ water column, DMSPt concentrations were $50 \pm 8 \mathrm{nM}$ at station $B$ and $74 \pm 10 \mathrm{nM}$ at station $\mathrm{E}$ (Table 3). Despite the observed differences in DMSPt, Chl, and to a lesser extent $N$, the DMS distributions were very similar at the two stations, with total-column averages of $3.3 \pm 0.6 \mathrm{nM}$ at station $\mathrm{B}$ and $3.2 \pm 0.8 \mathrm{nM}$ at station B. As emphasized in the right-hand column of Fig. 4, the two stations were virtually identical in terms of the average DMS concentrations. This observation suggested that it was reasonable to assume that horizontal DMS gradients in the region were 


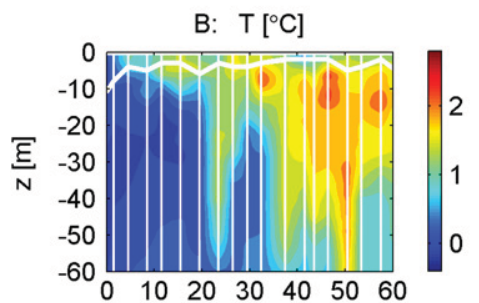

B: S

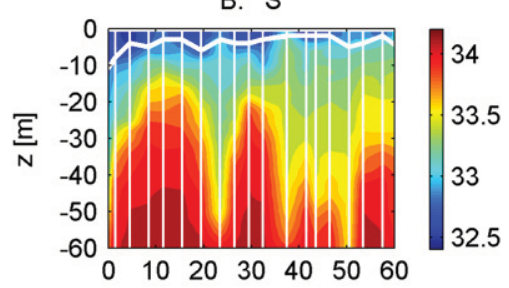

B: $\sigma_{\mathrm{t}}\left[\mathrm{kg} \mathrm{m}^{-3}\right]$

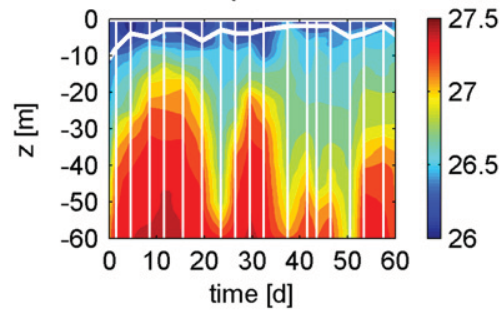

$\mathrm{E}: \mathrm{T}\left[{ }^{\circ} \mathrm{C}\right]$

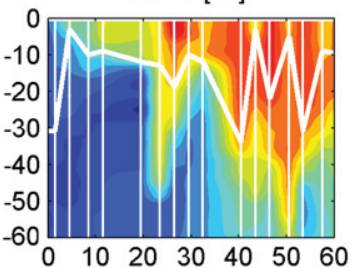

E: $S$

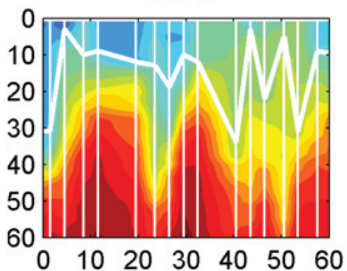

E: $\sigma_{\mathrm{t}}\left[\mathrm{kg} \mathrm{m}^{-3}\right]$

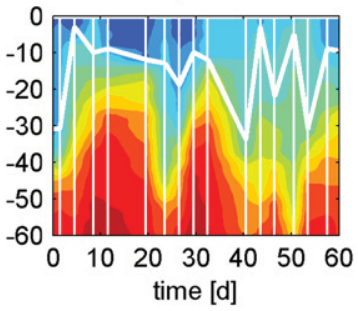

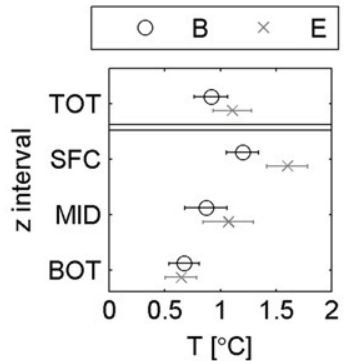
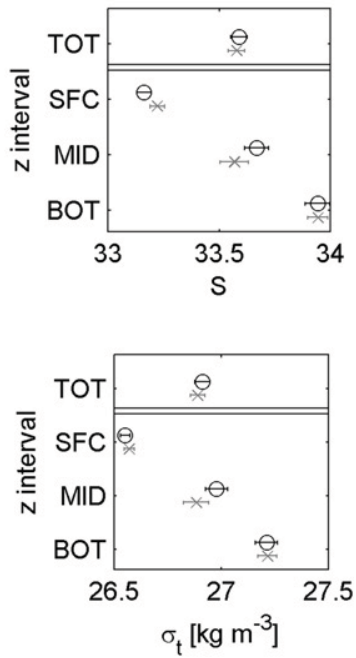

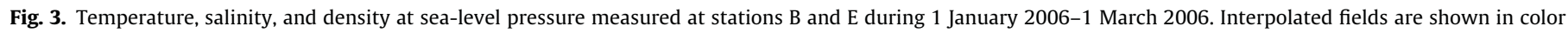
and observation times are indicated by light vertical lines to illustrate the extent of interpolation. Calculated mixed layer depth is shown as a thick white line (see Section 3.1).

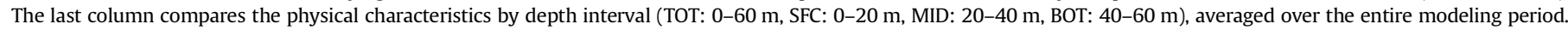

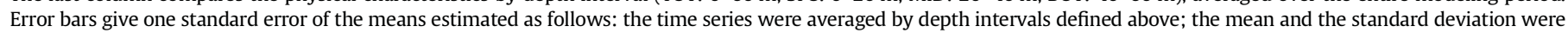
calculated for each depth-averaged time series; the standard error of the mean was estimated as the standard deviation divided by the square root of the number of elements in the time series. (For interpretation of the references to color in this figure legend, the reader is referred to the web version of this article.)

close to zero, which then can serve as a justification for neglecting the horizontal advection term in the DMS budget, as we have done.

\subsection{Diagnosed DMS budgets}

The time and depth-interval averaged DMS budget parameters for the base-run, i.e., measurement-based rate constants for microbial consumption $\left(k_{\text {mic }}\right)$ and photolysis $\left(k_{\text {phot }}\right)$, and model-based vertical eddy diffusivity $(v)$ and gas transfer coefficient $\left(k_{w}\right)$, are summarized in Fig. 5. Similar to the station characteristics discussed above, differences in the budget parameters between stations B and E were observed mostly in the surface layer $(0-20 \mathrm{~m})$. On average, $k_{\text {mic }}$ was slightly greater at station B. Average $k_{\text {phot }}$ was non-zero only in the surface layer for both stations, and was clearly greater at station E, which, according to our analysis, had lower light attenuation. Dierssen et al. (2002) reported that turbidity and radiance reflectance (ratio of upwelling radiance to downwelling irradiance) were about two times higher at station B compared with station E, based on the analysis of the LTER data from 1991 through 1999. The authors suggested that highly scattering minerogenic particles released by melt-water cause the water to be optically distinct from typical conditions and appear to sink out rapidly offshore, leading to dramatically different optical conditions at stations B and E. Average model $v$ and $k_{w}$ were practically indistinguishable at the two stations.

A summary of the diagnosed budgets for stations B and E is presented in Fig. 6. In the surface layer, the plotted rate of mixing represents a combination of two processes: turbulent mixing and gas exchange. At both stations, ventilation was about $8 \%$ of the total losses in the surface interval. Mixing can lead to both gains and losses of DMS, depending on the direction of eddy movement and the DMS concentration gradient. When averaged, mixing rates were very close to zero in the interior and acted as a very minor loss term for DMS in the surface interval, accounting for less than $1 \%$ of the total losses at both stations. Microbial consumption was the dominant loss term in both station budgets, in agreement with previous field experiments in Antarctic waters (del Valle et al., 2009) and in other oceanographic settings (Kieber et al., 1996; Vila-Costa et al., 2008). DMS loss to microbial consumption was stronger at station $\mathrm{B}$, while photolysis loss was stronger at station $\mathrm{E}$. In the surface interval, microbial consumption accounted for $80 \%$ and $66 \%$ of the total losses at stations B and $\mathrm{E}$, respectively, while photolysis represented $12 \%$ and $26 \%$ at stations $B$ and $\mathrm{E}$, respectively. The DMS production rate was approximately equal at both stations. It is to be noted that, since microbial DMS consumption rates were measured in dark incubations, and this process has proved susceptible to UV radiation-mediated inhibition (Toole et al., 2006), the biological DMS loss may have been overestimated, leading to overestimation of the diagnosed gross biological DMS production rates.

From our diagnostic analysis, the scale for all of the source terms in the DMS budget was on the order of $1-10 \mathrm{nM} \mathrm{d}^{-1}$. We used this scale information to provide additional justification for omitting the horizontal advection term in the DMS budget. The horizontal advection rate, $J_{a d v}$, in Eq. (1) can be scaled as

$J_{a d v} \sim U \frac{\Delta C}{L}$,

where $U$ is the horizontal velocity scale and $(\Delta C / L)$ is the scale for the horizontal gradient in the DMS concentration. According to 

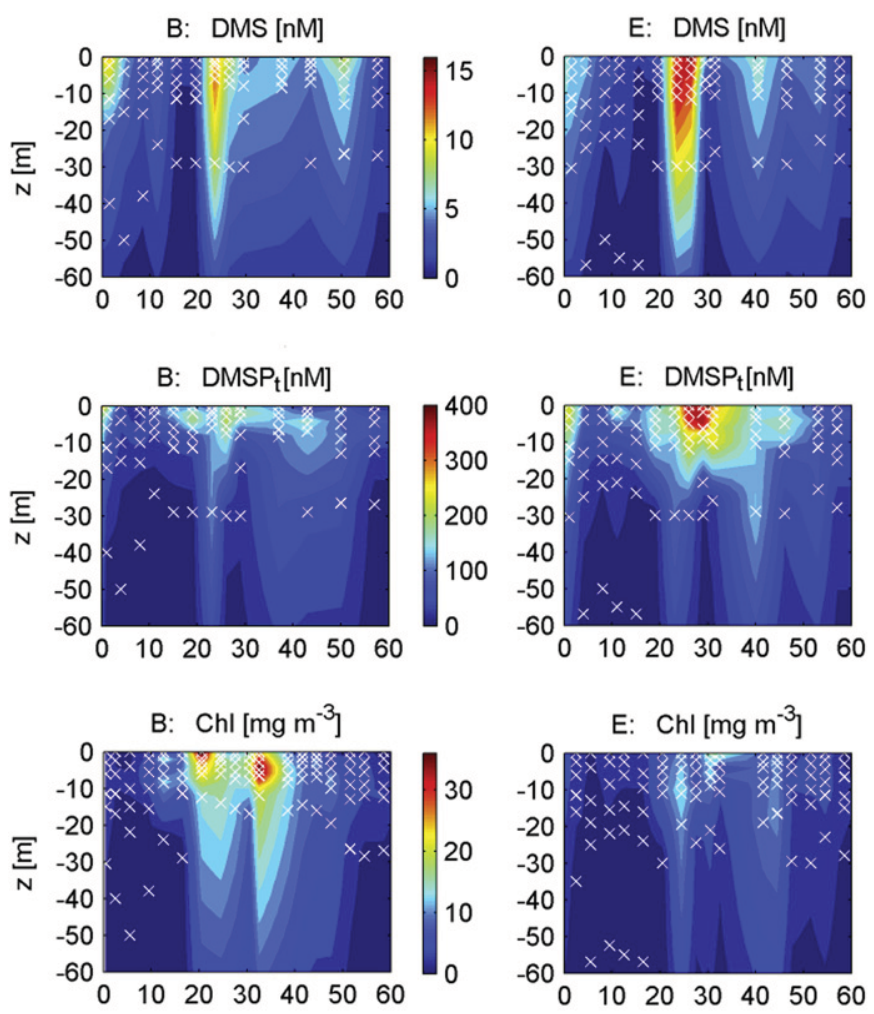

B: $N[\mu \mathrm{M}]$

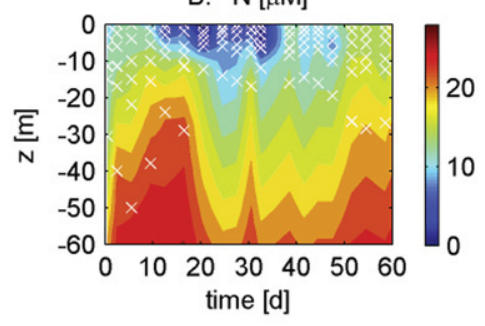

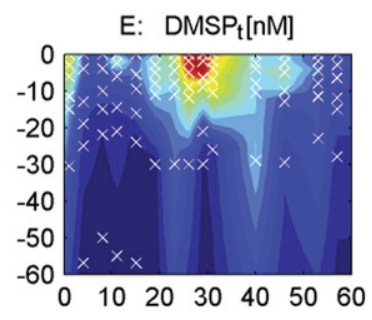

E: $\quad C h l\left[\mathrm{mg} \mathrm{m}^{-3}\right]$

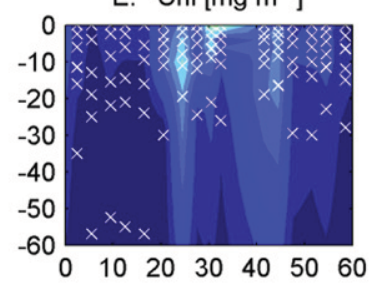

$\mathrm{E}: \mathrm{N}[\mu \mathrm{M}]$

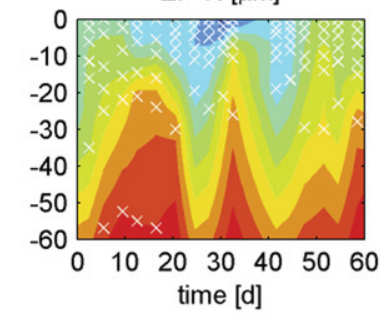

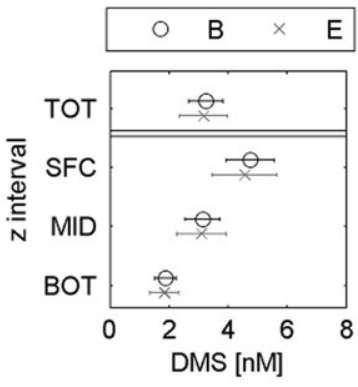
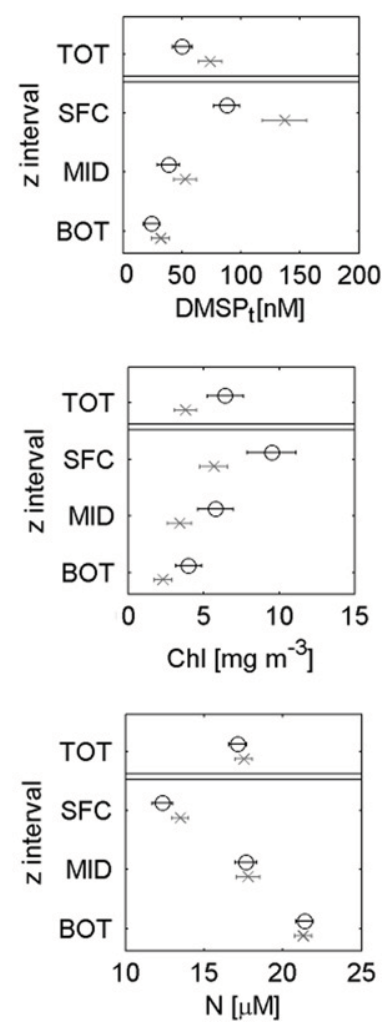

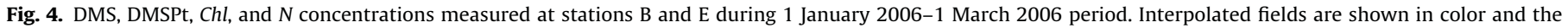

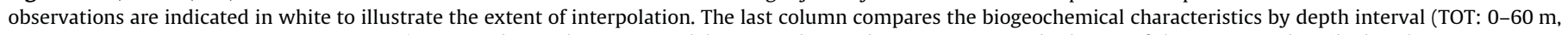

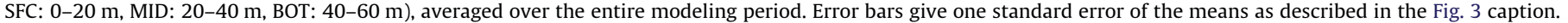
(For interpretation of the references to color in this figure legend, the reader is referred to the web version of this article.)

Table 3

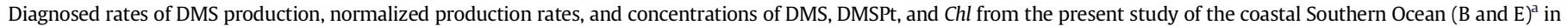
comparison with results from the Sargasso Sea study (C1 and A2) by Bailey et al. (2008).

\begin{tabular}{|c|c|c|c|c|c|c|c|}
\hline $\begin{array}{l}\text { Interval } \\
{[\mathrm{m}]}\end{array}$ & Station & $\begin{array}{l}\text { DMS } \\
{[\mathrm{nM}]}\end{array}$ & $\begin{array}{l}J_{\text {prod }} \\
{\left[\mathrm{nM} \mathrm{d}^{-1}\right]}\end{array}$ & $\begin{array}{l}\text { DMSPt } \\
{[\mathrm{nM}]}\end{array}$ & $\begin{array}{l}J_{\text {prod }} / \mathrm{DMSPt} \\
{\left[\left(\mathrm{nM} \mathrm{d}^{-1}\right) / \mathrm{nM}\right]}\end{array}$ & $\begin{array}{l}\text { Chl } \\
{\left[\mathrm{mg} \mathrm{m}^{-3}\right]}\end{array}$ & $\begin{array}{l}J_{\text {prod }} / \text { Chl } \\
{\left[\left(\mathrm{nM} \mathrm{d}^{-1}\right) /\left(\mathrm{mg} \mathrm{m}^{-3}\right)\right]}\end{array}$ \\
\hline $\begin{array}{l}0-60 \\
\text { TOT }\end{array}$ & $\begin{array}{l}\text { B } \\
\text { E } \\
\text { C1 } \\
\text { A2 }\end{array}$ & $\begin{array}{l}3.3 \pm 0.6 \\
3.2 \pm 0.8\end{array}$ & $\begin{array}{r}3.1 \pm 0.6 \\
2.7 \pm 0.6 \\
0.73 \pm 0.09 \\
0.9 \pm 0.12\end{array}$ & $\begin{array}{l}50 \pm 8 \\
74 \pm 10 \\
15.5 \\
10.4\end{array}$ & $\begin{array}{c}0.06 \pm 0.02 \\
0.04 \pm 0.01 \\
0.047 \pm 0.006 \\
0.087 \pm 0.014\end{array}$ & \begin{tabular}{l}
\multicolumn{1}{c}{$6 \pm 1$} \\
$3.8 \pm 0.7$ \\
0.063 \\
0.044
\end{tabular} & $\begin{array}{l}0.5 \pm 0.1 \\
0.7 \pm 0.2 \\
12 \pm 1 \\
20 \pm 3\end{array}$ \\
\hline $\begin{array}{l}0-20 \\
\text { SFC }\end{array}$ & $\begin{array}{l}\text { B } \\
\text { E } \\
\text { C1 } \\
\text { A2 }\end{array}$ & $\begin{array}{l}4.7 \pm 0.8 \\
4.6 \pm 0.1\end{array}$ & $\begin{array}{c}5 \pm 1 \\
5 \pm 1 \\
0.64 \pm 0.09 \\
0.78 \pm 0.09\end{array}$ & $\begin{array}{l}88 \pm 11 \\
137 \pm 19 \\
10.8 \\
7.5\end{array}$ & $\begin{array}{c}0.06 \pm 0.01 \\
0.04 \pm 0.01 \\
0.058 \pm 0.008 \\
0.104 \pm 0.012\end{array}$ & \begin{tabular}{l}
\multicolumn{1}{c}{$9 \pm 2$} \\
$5.7 \pm 0.9$ \\
0.040 \\
0.033
\end{tabular} & $\begin{array}{l}0.5 \pm 0.1 \\
0.9 \pm 0.3 \\
15 \pm 2 \\
22 \pm 3\end{array}$ \\
\hline $\begin{array}{l}20-40 \\
\text { MID }\end{array}$ & $\begin{array}{l}\text { B } \\
\text { E } \\
\text { C1 } \\
\text { A2 }\end{array}$ & $\begin{array}{l}3.1 \pm 0.6 \\
3.1 \pm 0.8\end{array}$ & $\begin{array}{c}2.7 \pm 0.5 \\
1.7 \pm 0.4 \\
0.91 \pm 0.14 \\
1.14 \pm 0.16\end{array}$ & $\begin{array}{l}39 \pm 9 \\
53 \pm 10 \\
14.5 \\
9.5\end{array}$ & $\begin{array}{c}0.07 \pm 0.02 \\
0.03 \pm 0.01 \\
0.062 \pm 0.010 \\
0.120 \pm 0.017\end{array}$ & $\begin{array}{l}\quad 6 \pm 1 \\
3.4 \pm 0.8 \\
0.055 \\
0.040\end{array}$ & $\begin{array}{l}0.5 \pm 0.1 \\
0.5 \pm 0.2 \\
15 \pm 3 \\
28 \pm 4\end{array}$ \\
\hline $\begin{array}{l}40-60 \\
\text { BOT }\end{array}$ & $\begin{array}{l}\text { B } \\
\text { E } \\
\text { C1 } \\
\text { A2 }\end{array}$ & $\begin{array}{l}1.9 \pm 0.4 \\
1.8 \pm 0.5\end{array}$ & $\begin{array}{c}1.4 \pm 0.3 \\
1.0 \pm 0.2 \\
0.64 \pm 0.10 \\
0.78 \pm 0.15\end{array}$ & $\begin{array}{l}24 \pm 7 \\
32 \pm 8 \\
21.3 \\
14.1\end{array}$ & $\begin{array}{c}0.06 \pm 0.02 \\
0.03 \pm 0.01 \\
0.030 \pm 0.005 \\
0.055 \pm 0.011\end{array}$ & $\begin{array}{l}4.0 \pm 0.9 \\
2.3 \pm 0.6 \\
0.095 \\
0.059\end{array}$ & $\begin{array}{c}0.4 \pm 0.1 \\
0.5 \pm 0.2 \\
7 \pm 1 \\
13 \pm 3\end{array}$ \\
\hline
\end{tabular}

${ }^{\text {a }}$ For normalized rates, the error bars give the combined error due to the propagated uncertainty in $J_{\text {prod }}$ (determined as described in Section 2.3.7) and the standard

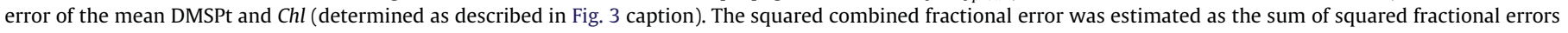
in the components, assuming that the error-contributing variables were uncorrelated. 

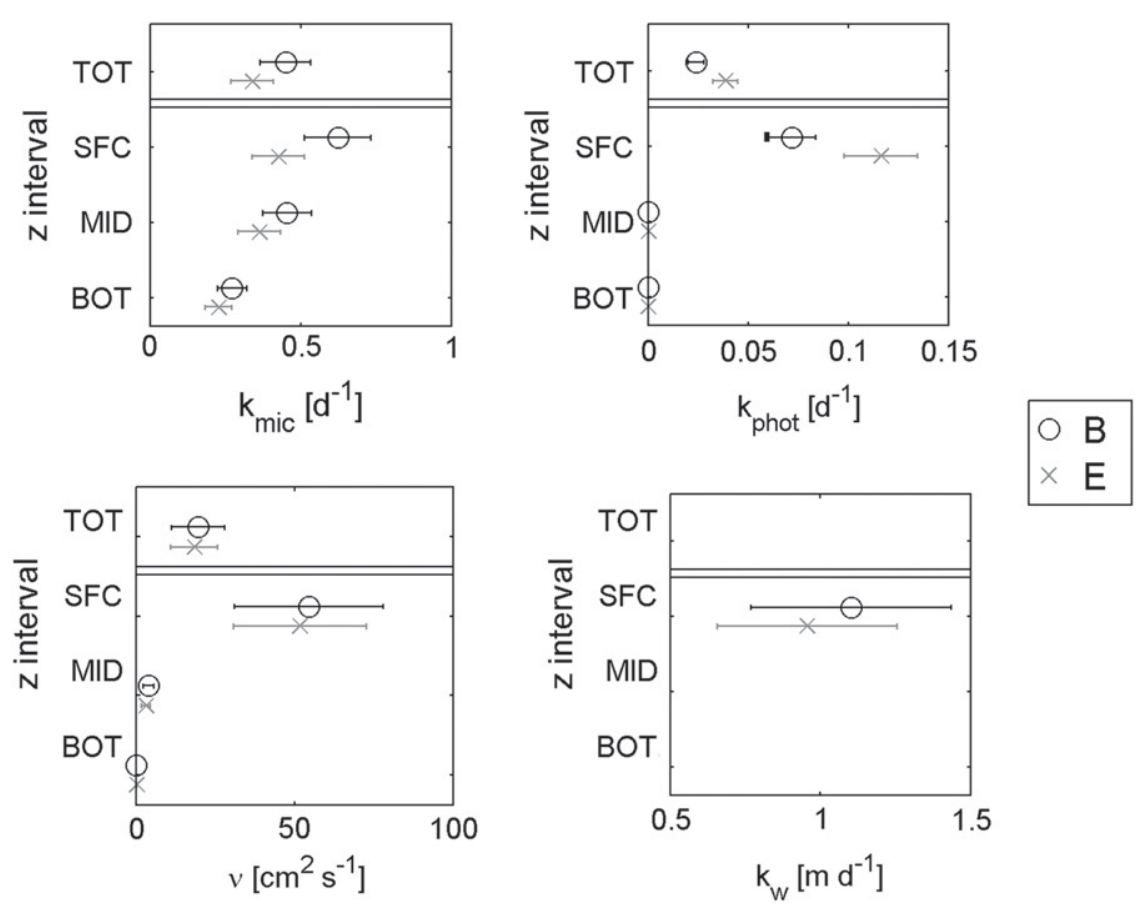

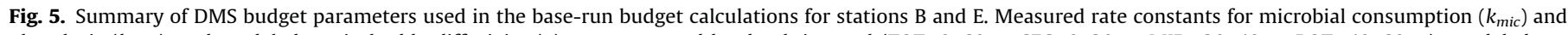
photolysis $\left(k_{\text {phot }}\right)$, and modeled vertical eddy diffusivity $(v)$ were averaged by depth interval (TOT: 0-60 m, SFC: 0-20 m, MID: 20-40 m, BOT: 40-60 m); modeled gas transfer coefficients $\left(k_{w}\right)$ are for the surface model grid box only. All parameters were averaged over the entire modeling period (1 January 2006-1 March 2006). Error bars give one standard error of the means determined as described in the Fig. 3 caption.

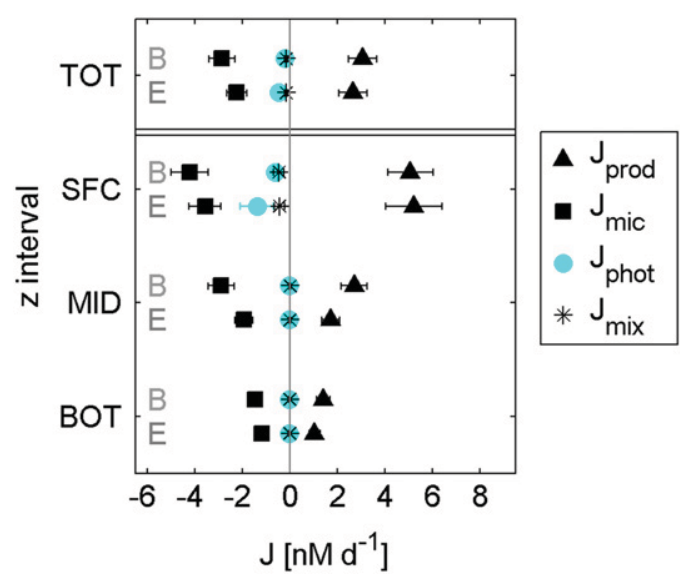

Fig. 6. Diagnosed DMS budgets for stations B and E. The DMS production rate $\left(J_{\text {prod }}\right)$, combined rate of mixing and gas exchange $\left(J_{m i x}\right)$, microbial consumption rate $\left(J_{\text {mic }}\right)$, and photolysis rate $\left(J_{\text {phot }}\right)$ are averaged by depth interval (TOT: 0-60 m, SFC: 0-20 m, MID: 20-40 m, BOT: 40-60 m) and over the entire modeling period (1 January 2006-1 March 2006). Error bars give estimated uncertainty in model outputs calculated by propagation of errors from the model input variables (see Section 2.3.7).

Smith et al. (1999) and Klinck et al. (2004), surface currents in the region are $\sim 0.01 \mathrm{~m} \mathrm{~s}^{-1}$. We used the average DMS concentration difference between stations $B$ and $E$ from our analysis (Fig. 5) to approximate $\Delta C \sim 0.1 \mathrm{nM}$, and the horizontal distance between the stations, $L$, is approximately $5000 \mathrm{~m}$. We estimated the scale for the horizontal advection rate at $J_{a d v} \sim 0.01 \mathrm{nM} \mathrm{d}^{-1}$, which is between two and three orders of magnitude smaller than the other source terms in the DMS budget.

\subsection{Diagnosed rates of DMS production}

Total column-averaged time series of DMS production were compared with the biogeochemical parameters in Fig. 7. The patterns emerging from this comparison were similar for both stations. Notwithstanding the uncertainty, there were two peaks in the production rates - around Julian days 23 and 40 - reaching close to $7 \mathrm{nM} \mathrm{d}^{-1}$, while background rates were less than $5 \mathrm{nM} \mathrm{d}^{-1}$. Peaks in DMS production were reasonably well aligned with peaks in DMSPt and $\mathrm{Chl}$ and with minima in $N$ concentrations. A strong storm event occurred around January 23, with wind speeds reaching up to $25 \mathrm{~m} \mathrm{~s}^{-1}$ and the atmospheric pressure decreasing by $22 \mathrm{hPa}$, down to $973 \mathrm{hPa}$, over the course of the day (Fig. 2). The wind was predominantly from the north, changing from northeasterly to northwesterly as the storm progressed. There were clear increases in observed DMS and DMSPt concentrations (Fig. 4) and a spike in diagnosed DMS production (Fig. 7) during the storm, suggesting a possible storm-induced stress related DMS production. Peaks in DMSPt concentrations were slightly higher at station $\mathrm{E}$, which is located further offshore and could have been affected more by the storm because of less sheltering by the surrounding land masses. However, because the error bars in diagnosed production rates overlapped, we were unable to detect a difference in the DMS production at the two stations in response to the storm. Another possible cause for the observed increase in DMS and DMSPt concentrations could have been upwelling of water from near the sediment-water interface, where sediment-derived sources of DMS and DMSP might have existed, as has been shown, for example, for the coastal zones of Northern Europe (Nedwell et al., 1994; Belviso et al., 2006) and for the Ross Sea, Antarctica (DiTullio et al., 2000). As emphasized in Fig. 4, our coverage of the deeper layer of the water column was sparse with few measurements collected below $30 \mathrm{~m}$ depth because the study focused on the upper water column processes; thus, we cannot conclusively attest whether the sediment source of DMS and DMSP was present in our study area. Because our stations are fairly shallow, extending to the depths of $\sim 80 \mathrm{~m}$ (station B) and $\sim 172 \mathrm{~m}$ (station $\mathrm{E}$ ), it is possible that a sediment source may affect upper water column concentrations during a deep mixing event. However, such transport of bottom water 

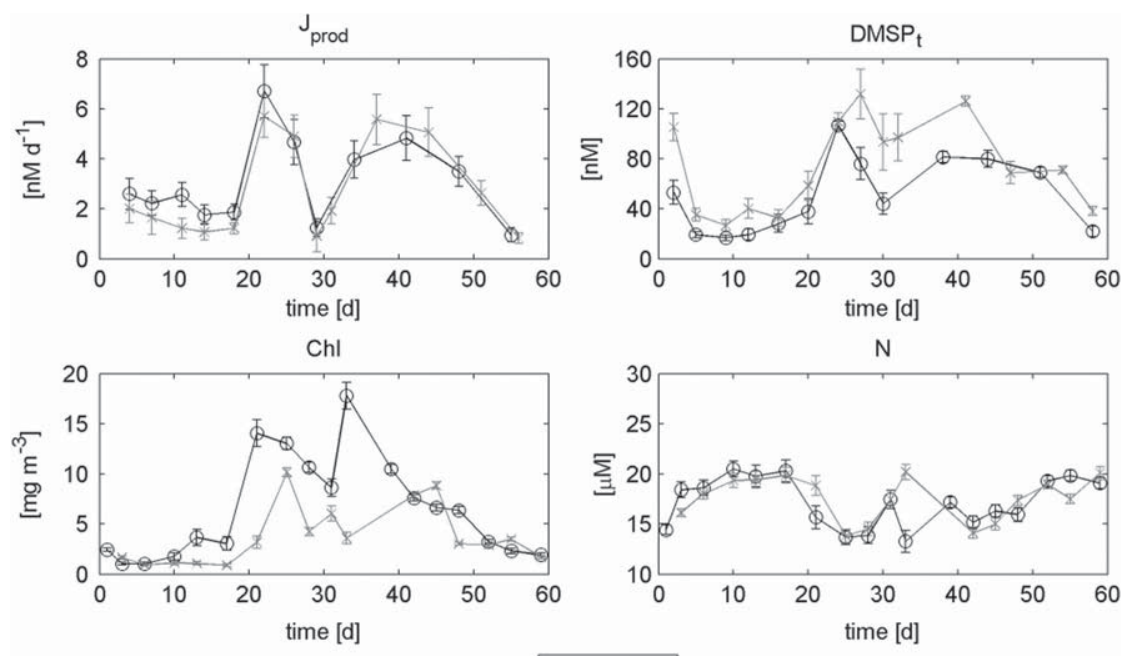

B $\times E$

Fig. 7. Time series of the diagnosed DMS production rate $\left(J_{\text {prod }}\right)$, DMSPt, $C h l$, and $N$ for stations B and E between 1 January 2006 and 1 March 2006 . Time series are averaged over the entire model water column $(0-60 \mathrm{~m})$. For $J_{\text {prod }}$, error bars give estimated uncertainty in model output calculated by propagation of errors in the model input variables (see Section 2.3.7). For DMSPt, $C h l$, and nitrate $(N)$ concentrations, error bars give one standard error of the means estimated as the standard deviation divided by the square root of the number of elements in each vertical profile.
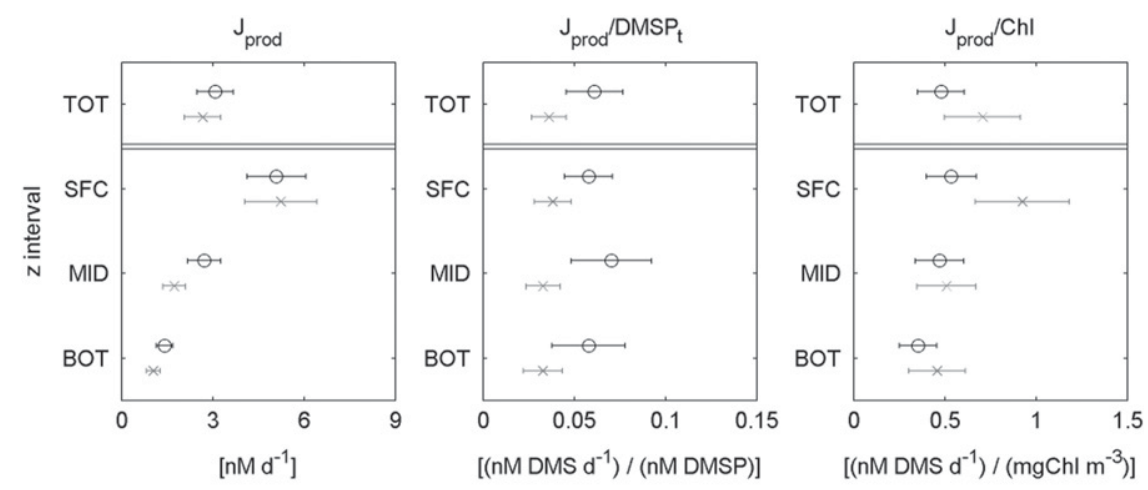

Fig. 8. Diagnosed DMS production rates $\left(J_{\text {prod }}\right)$, production rates normalized to DMSPt ( $\left.J_{\text {prod }} / \mathrm{DMSPt}\right)$, and production rates normalized to $C h l\left(J_{\text {prod }} / C h l\right)$ for stations B and E. Rates were averaged by depth interval (TOT: 0-60 m, SFC: 0-20 m, MID: 20-40 m, BOT: 40-60 m) and over the entire modeling period (1 January 2006-1 March 2006). For $J_{\text {prod }}$, error bars give the estimated uncertainty in model output calculated by propagation of errors from the model input variables. For normalized rates, error bars give the combined error due to the propagated uncertainty in $J_{\text {prod }}$ (see Section 2.3.7) and the standard error of the mean DMSPt and Chl (determined as described in Fig. 3 caption).

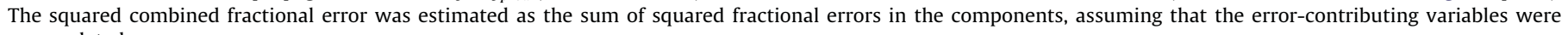
uncorrelated.

would have required overturning of the seasonal stratification and mixing of the entire water column, which was unlikely during stable summer stratification. In addition, based on the available deep profiles, both DMS and DMSPt concentrations showed a clear decrease with depth (Fig. 4) and the depth of the mixed layer did not exceed $30 \mathrm{~m}$ at either station (Fig. 3), which also implies that a sediment source was unlikely.

A depth-interval summary of diagnosed production rates, and production rates normalized to DMSPt or Chl concentrations is given in Fig. 8. Averaged over the entire water column, diagnosed DMS production rates at stations $B$ and $E$ were $3.1 \pm 0.6$ and $2.7 \pm 0.6 \mathrm{nM} \mathrm{d}^{-1}$, respectively. At both stations, the average production rate of DMS in the surface mixed layer was about two times higher than in the interior. Averaged over the entire water column, the ratio of DMS production to $\mathrm{Chl}$ at station $\mathrm{E}$ was slightly higher than at station $\mathrm{B}(0.7 \pm 0.2$ and $0.5 \pm 0.1$ (nM DMS d $\left.{ }^{-1}\right) /\left(\mathrm{mg} \mathrm{Chl} \mathrm{m}^{-3}\right)$, respectively). On the other hand, DMS production rates normalized to DMSPt standing stock were slightly higher at station B at all depths. Averaged over the entire column, the DMSPt-normalized DMS production was $0.06 \pm 0.02\left(\mathrm{nM} \mathrm{DMS} \mathrm{d}^{-1}\right) /(\mathrm{nM}$ DMSP) at station B and $0.04 \pm 0.01$ $\left(\mathrm{nM} \mathrm{DMS} \mathrm{d}{ }^{-1}\right) /(\mathrm{nM}$ DMSP) at station E.

Averaging both stations, the DMS production rate in the water column that we inferred through our diagnostic calculation was $2.9 \pm 0.4 \mathrm{nM} \mathrm{d}^{-1}$. Combining this estimate with the average observed DMS concentration of $\sim 3 \mathrm{nM}$, we estimated the DMS replacement time - DMS concentration divided by gross production rate - to be on the order of $1 \mathrm{~d}$, which was similar to the average DMS replacement time estimated by Galí and Simó (2010) in productive Arctic waters in the summer, and at the lower end of turnover times estimated for microbial DMS consumption reported in a wide range of oceanographic settings (Simó and Pedrós-Alió, 1999).

\section{Discussion}

Observed peaks in the diagnosed production rates at stations B and $\mathrm{E}$ approximately followed the maxima in $\mathrm{Chl}$ concentrations 
(Fig. 7), consistent with the bloom regime of DMS production concept proposed by Toole and Siegel (2004). Moreover, we found a significant positive correlation between observed $\mathrm{Chl}$ concentrations and the diagnosed DMS production rates (Fig. 9), indicating that phytoplankton biomass is a strong driver of DMS production in the Antarctic Peninsula study area.

We compare our results with the results of other DMS studies conducted in the Southern Ocean region and with a diagnostic DMS study in the contrasting biogeochemical environment in the North Atlantic subtropical gyre by Bailey et al. (2008).

\subsection{Comparison with previous studies in the Southern Ocean}

Berresheim et al. (1998) reported DMS concentrations in the surface waters near Palmer Station ranging between 0.7 and 3.7 nM during January-February 1994, which was slightly below the values we observed in January-March $2006(5.6 \pm 3.4 \mathrm{nM}$ at station $B$ and $5.5 \pm 4.2 \mathrm{nM}$ at station $E$ ). In a different location in the Southern Ocean, a similar temporal evolution of DMS, DMSPt, and $\mathrm{Chl}$ concentrations to our January-March 2006 observations was described by Gambaro et al. (2004) for the Gerlache Inlet (Terra Nova Bay, Ross Sea, Antarctica), with two clear maxima. Our observed DMS concentrations, however, were approximately an order of magnitude lower than in the Gerlache Inlet study. In another study in the vicinity of Gerlache Inlet, Kiene et al. (2007) reported surface water measurements along three transects between $49^{\circ} \mathrm{S}$ and $76^{\circ} \mathrm{S}$, in the New Zealand sector of the Southern Ocean, from November 2003, December 2004, and November 2005. In open waters, DMS concentrations ranged between 0.6 and $3.2 \mathrm{nM}$, but reached up to $30 \mathrm{nM}$ at the northern boundaries of the seasonal sea-ice $\left(63^{\circ} \mathrm{S}-68^{\circ} \mathrm{S}\right)$ and in the northern Ross Sea. Good agreement with our observations was

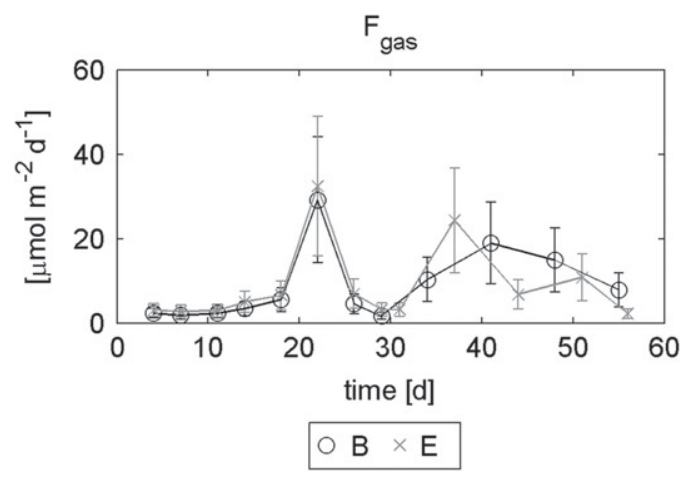

Fig. 9. Scatter plots of diagnosed DMS production rates $\left(J_{\text {prod }}\right)$ and observed $C h l$ concentrations averaged over the surface interval $(0-20 \mathrm{~m})$ for stations B and E. Also shown are the correlation coefficients and the associated $p$-values. also found in the study by Jones et al. (2010) in the south-west Indian Ocean sector of East Antarctica, from $30^{\circ} \mathrm{E}$ to $80^{\circ} \mathrm{E}$ and south of $62^{\circ} \mathrm{S}$, from January to March 2006. Surface DMS concentrations ranged from non-detectable to $48 \mathrm{nM}$, with a mean value of $10 \mathrm{nM}$, which was slightly higher than our average concentrations. Further east, also in the Australian sector of the Southern Ocean $\left(63^{\circ} \mathrm{E}-162^{\circ} \mathrm{E}, 40^{\circ} \mathrm{S}-69^{\circ} \mathrm{S}\right)$, Curran and Jones (2000) reported a monthly average surface water DMS concentration of $7.9 \mathrm{nM}$ for the spring and summer seasons from 1991 to 1995 in the seasonal ice zone, which is comparable to average DMS concentrations observed in our study.

DMSPt concentrations reported by Kiene et al. (2007) ranged from 12 to $52 \mathrm{nM}$ in the open waters and reached up to $95 \mathrm{nM}$ at the seasonal sea-ice boundary and in the Ross Sea. While our DMSPt concentrations agree on average, on several occasions we detected much higher DMSPt concentrations, reaching up to $400 \mathrm{nM}$ at station E. This may reflect much higher phytoplankton

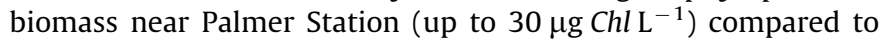

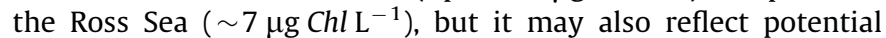
losses of DMSPt during preservation of Ross Sea samples containing colonial Phaeocystis antarctica (del Valle et al., 2010). Lower mean surface DMSPt concentrations, ranging from 10 to $52 \mathrm{nM}$, with a mean of $29 \mathrm{nM}$, were also reported for the Australian sector by Jones et al. (2010).

With respect to DMS losses, our estimates of biological DMS consumption in the surface layer $(0-20 \mathrm{~m})$ ranged from 2 to $7 \mathrm{nM} \mathrm{d}^{-1}(4.2 \pm 0.8)$ at station $\mathrm{B}$ and from 1 to $8 \mathrm{nM} \mathrm{d}^{-1}$ $(3.6 \pm 0.7)$ at station $\mathrm{E}$. These rates are in the same range as those measured in the Ross Sea, up to $8.8 \mathrm{nM} \mathrm{d}^{-1}$ (Kiene et al., 2007; del Valle et al., 2009). Curran and Jones (2000) reported an average gas flux from the seasonal ice zone of $49 \mu \mathrm{mol} \mathrm{m}^{-2} \mathrm{~d}^{-1}$, for an average wind speed of $11.7 \mathrm{~m} \mathrm{~s}^{-1}$. In our study, the average wind speed was $3.5 \mathrm{~m} \mathrm{~s}^{-1}$, and the estimated gas fluxes were slightly lower, ranging between 2 and $32 \mu \mathrm{mol} \mathrm{m}^{-2} \mathrm{~d}^{-1}$ (Fig. 10). In addition, Curran and Jones (2000) estimated the DMS emissions in the Antarctic region of the Southern Ocean (south of the Polar Front, about $55^{\circ} \mathrm{S}$ ), excluding contributions form sea-ice, at $85 \mathrm{Gmol} \mathrm{S} \mathrm{yr}^{-1}$, representing $10 \%$ of the mean global emission estimate of $880 \mathrm{Gmol} \mathrm{S} \mathrm{yr}^{-1}$ provided by Lana et al. (2011) from $6 \%$ of the global ocean surface area. These results suggest that the Southern Ocean and, in particular, the seasonal ice zone, is an important DMS source, emphasizing the need of continued study of DMS dynamics in this region.

In summary, the DMS concentrations observed in our study are in good agreement with other studies in the Southern Ocean. The same is true about modeled air-sea DMS flux and microbial DMS consumption rates. Observed DMSPt concentrations appear higher than what is reported in other studies. To the best of our knowledge, there are no published estimates of gross biological DMS production in the Southern Ocean and, therefore, we are unable to compare our diagnosed rates with observations from literature.
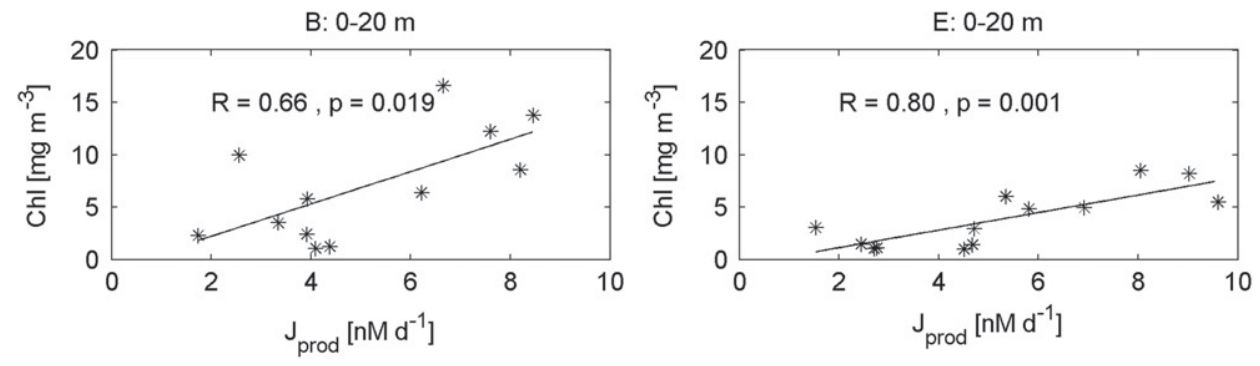

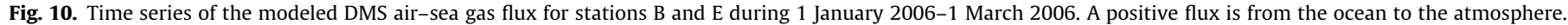
Error bars give the estimated uncertainty in model output calculated by propagation of errors in the model input variables (see Section 2.3.7). 
4.2. Comparison with a previous study in the North Atlantic Subtropical gyre

We compared our results with the results of a diagnostic DMS study in the North Atlantic subtropical gyre by Bailey et al. (2008), referred to as B08 hereafter (Table 3). The B08 study used a similar modeling approach to estimate gross biological DMS production in two eddies in the Sargasso Sea, a downwelling ocean region characterized by low nutrient concentrations and extremely low primary productivity in the summer. Therefore, B08 and the present study of the coastal Southern Ocean region describe two contrasting biogeochemical ocean environments. Average gross biological DMS production in the water column estimated in the present study $\left(2.9 \pm 0.4 \mathrm{nM} \mathrm{d}^{-1}\right)$ was about three times greater than in B08. The DMS replacement time estimated in the present study was on the order of $1 \mathrm{~d}$, which was shorter than in B08, where the reported replacement time was between 4 and $9 \mathrm{~d}$, indicating faster DMS turnover in the Antarctic coastal waters despite much lower temperatures (1-2 ${ }^{\circ} \mathrm{C}$ at Palmer Station vs. $\sim 30{ }^{\circ} \mathrm{C}$ in the Sargasso Sea). Gross production in B08 was the greatest below the mixed layer, whereas in the present study gross production was the greatest within the mixed layer. Compared with our estimates, gross biological DMS production normalized to $\mathrm{Chl}$ was about an order of magnitude higher in B08. This likely reflected the differences in the composition of phytoplankton assemblage and the low phytoplankton biomass in the Sargasso Sea surface waters in summer. Average DMSPt:Chl ratios were an order of magnitude

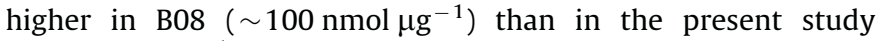
$\left(\sim 10 \mathrm{nmol} \mu \mathrm{g}^{-1}\right)$, again due to low chlorophyll biomass, as the Antarctic DMSPt concentrations were 5-fold higher, on average, than in B08, and up to 400-fold higher in surface waters. We found, however, a striking similarity in production rates normalized to DMSPt concentrations, suggesting a strong underlying similarity between two contrasting biogeochemical environments in terms of DMSPt-DMS conversion. The significance of this finding of near constancy of DMSPt-DMS conversion ratio across pelagic biomes is that it could provide a means to use DMSPt measurements to extrapolate gross DMS production, which is extremely difficult to measure experimentally.

B08 conducted a comparison of their DMS production estimates with those reported in literature for other ocean regions and pointed out that the range in reported DMS gross production rates spans nearly three orders of magnitude, from $\sim 0.6$ to $500 \mathrm{nM} \mathrm{d}^{-1}$. After normalizing to DMSPt, however, the range covers only about an order of magnitude, from 0.05 to $0.7\left(\mathrm{nM} \mathrm{DMS} \mathrm{d}^{-1}\right) /$ (nM DMSP). Averaging the results of B08 with the results of the present study, our estimate of mean gross biological DMS production normalized to DMSPt concentration, independent of the biogeochemical environment, is $0.06 \pm 0.01\left(\mathrm{nM} \mathrm{DMS} \mathrm{d}^{-1}\right) /(\mathrm{nM}$ DMSP). This represents a conversion of about $6 \%$ of the standing stock of DMSP into DMS per day, a value consistent with the bulk of DMSPsulfur being diverted to non-DMS metabolites (Kiene and Linn, 2000; Howard et al., 2006).

\subsection{Inference about global marine DMS production}

Lastly, we used our estimate of average DMSPt-normalized DMS production to make a first, albeit crude, observation-based estimate of the magnitude of global marine gross biological DMS production. Kettle et al. (1999) estimated global-median surfaceocean dissolved and particulate DMSP concentrations at $9.7 \mathrm{nM}$ and $20.5 \mathrm{nM}$, respectively, from which we inferred, by summation, a global-median surface-ocean DMSPt concentration of $30 \mathrm{nM}$. Reported dissolved and particulate DMSP medians were computed from data binned onto a 1-degree grid by calendar month (about 1000 values for each quantity). We chose to use the median rather than the mean as a measure of the central tendency of the global DMSPt concentration in the calculation because Kettle et al. (1999) emphasized that the distribution of the binned data was strongly non-Gaussian, skewed towards lower values. We subjectively estimated that the median DMSPt concentration has an error of $\pm 50 \%$. Multiplying this estimate by our DMSPt-normalized DMS production gives a global average surface ocean gross DMS production estimate of $2 \pm 1 \mathrm{nM} \mathrm{d}^{-1}$. Assuming that this DMS production occurs in the upper $100 \mathrm{~m}$ and using the global ocean area of $3.6 \times 10^{8} \mathrm{~km}^{2}$, we arrive at a global ocean gross DMS production rate of $24 \pm 13 \mathrm{Tmol} \mathrm{S} \mathrm{yr}^{-1}$. Using the Lana et al. (2011) global estimate of the sea-to-air DMS flux, $0.88 \mathrm{Tmol} \mathrm{S} \mathrm{yr}^{-1}$ (range from 0.55 to $1.08 \mathrm{Tmol} \mathrm{S} \mathrm{yr}^{-1}$ ), DMS gas emissions represent $4 \pm 2 \%$ of marine gross DMS production globally. In a global modeling study, Kloster et al. (2006) simulated DMS gas emissions of $0.88 \mathrm{Tmol} \mathrm{S} \mathrm{yr}^{-1}$, in agreement with Lana et al. (2011), and marine DMS production of $11 \mathrm{Tmol} \mathrm{S} \mathrm{yr}^{-1}$, which is about half of our estimate. Despite these differences, these independent estimates both arrive at the same conclusion that, at the global scale, the DMS flux from the ocean to the atmosphere is only a small fraction of the marine DMS production.

\section{Summary and conclusions}

We estimated gross biological DMS production in the coastal environment west of the Antarctic Peninsula using in situ estimates of chemical and biological loss terms in the DMS budget and the observed variability in concentrations of DMS and related tracers. The calculations were based on water-column measurements collected during the DMS field campaign and a physical model of ocean mixing. Averaged over the entire water column, diagnosed gross biological DMS production rates were $3.1 \pm 0.6 \mathrm{nM} \mathrm{d}^{-1}$ at station B and $2.7 \pm 0.6 \mathrm{nM} \mathrm{d}^{-1}$ at station E. Production rates were at a maximum in the mixed layer at both stations. The ratio of DMS production to Chl was $0.7 \pm 0.2$ and $0.5 \pm 0.1\left(\mathrm{nM} \mathrm{DMS} \mathrm{d}^{-1}\right) /\left(\mathrm{mg} \mathrm{Chl} \mathrm{m}^{-3}\right)$ at stations B and E, respectively. The DMSPt-normalized gross biological DMS production was $0.06 \pm 0.02\left(\mathrm{nM} \mathrm{DMS} \mathrm{d}^{-1}\right) /(\mathrm{nM}$ DMSP $)$ at station $\mathrm{B}$ and $0.04 \pm 0.01\left(\mathrm{nM} \mathrm{DMS} \mathrm{d}^{-1}\right) /(\mathrm{nM}$ DMSP) at station E. It should be emphasized that our field campaign did not include measurements of turbulent mixing and gas exchange processes; therefore, these processes add considerable uncertainty to our results because their treatment was entirely model-based in our calculations. Future studies should include direct measurements of mixing and gas exchange processes in order to have data that could be used for model calibration.

A comparison of our results with the results of a diagnostic DMS study in the North Atlantic subtropical gyre by Bailey et al. (2008) revealed that the production rates normalized to DMSPt concentrations were very similar in the two contrasting biogeochemical ocean environments. The significance of this finding of near constancy of DMSPt-DMS conversion ratio across pelagic biomes is that it could provide a means to use DMSPt measurements to extrapolate gross biological DMS production, which is difficult to measure in situ. We estimated that mean gross biological DMS production normalized to DMSPt concentration, independent of the biogeochemical environment, is $0.06 \pm 0.01$ (nM DMS d $\left.^{-1}\right) /(\mathrm{nM}$ DMSP). Combining this estimate with currently available values for global-median surface-ocean DMSP concentrations (Kettle et al., 1999) suggests a global ocean gross biological DMS production rate of $24 \pm 13 \mathrm{Tmol} \mathrm{S} \mathrm{yr}^{-1}$. 


\section{Acknowledgments}

We are grateful to the GOTM-developer team: Hans Burchard, Karsten Bolding, Lars Umlauf, and Hannes Rennau. We also deeply appreciate the logistical collaboration and support of the Palmer Station LTER and the resident teams at the time of the field campaign, with special thanks to K. McElroy and G.R. Westby. This research was supported by the National Science Foundation (NSF) Office of Polar Programs (OPP) under Grant OPP-0083078 to P.A. Matrai. Data from the Palmer LTER data archive were supported by NSF Grant OPP-0217282. Meteorological data were supported by NSF Grants OPP-0537827, OPP-0338147, and OPP-0230028. Surface solar radiation data were provided by the NSF UV Monitoring Network, operated by Biospherical Instruments Inc. under a contract from the NSF OPP via Raytheon Polar Services Company.

\section{References}

Ayers, G.P., Gillett, R.W., 2000. DMS and its oxidation products in the remote marine atmosphere: implications for climate and atmospheric chemistry. Journal of Sea Research 43, 275-286.

Bailey, K.E., Toole, D.A., Blomquist, B., Najjar, R.G., Huebert, B., Kieber, D.J., Kiene, R.P., Matrai, P., Westby, G.R., del Valle, D.A., 2008. Dimethylsulfide production in Sargasso Sea eddies. Deep-Sea Research II 55, 1491-1504.

Belviso, S., Thouzeau, G., Schmidt, S., Reigstad, M., Wassmann, P., Arashkevich, E. Stefels, J., 2006. Significance of vertical flux as a sink for surface water DMSP and as a source for the sediment surface in coastal zones of northern Europe. Estuarine, Coastal and Shelf Science 68, 473-488.

Berresheim, H., Huey, J.W., Thorn, R.P., Eisele, F.L., Tanner, D.J., Jefferson, A., 1998. Measurements of dimethyl sulfide, dimethyl sulfoxide, dimethyl sulfone, and aerosol ions at Palmer Station, Antarctica. Journal of Geophysical Research 103, 1629-1637.

Blomquist, B.W., Fairall, C.W., Huebert, B.J., Kieber, D.J., Westby, G.R., 2006. DMS sea-air transfer velocity: direct measurements by eddy covariance and parameterization based on the NOAA/COARE gas transfer model. Geophysical Research Letters 33, 1-4.

Burchard, H., Bolding, K., Villarreal, M.R., 1999. GOTM—a general ocean turbulence model. Theory, applications and test cases. European Commission Report EUR 18745.

Chang, G.C., Dickey, T.D., 2004. Coastal ocean optical influences on solar transmission and radiant heating rate. Journal of Geophysical Research 109, C01020.

Charlson, R.J., Lovelock, J.E., Andreae, M.O., Warren, S.G., 1987. Oceanic phytoplankton, atmospheric sulphur, cloud albedo and climate. Nature 326, 655-661.

Curran, M.A.J., Jones, G.B., 2000. Dimethyl sulfide in the Southern Ocean: seasonality and flux. Journal of Geophysical Research 105, 20451-20459.

Dierssen, H.M., Smith, R.C., Vernet, M., 2002. Glacial meltwater dynamics in coastal waters west of the Antarctic Peninsula. Proceedings of the National Academy of Sciences 99, 1790-1795.

DiTullio, G.R., Grebmeier, J.M., Arrigo, K.R., Lizotte, M.P., Robinson, D.H., Leventer A., Barry, J.P., VanWoert, M.L., Dunbar, R.B., 2000. Rapid and early export of Phaeocystis antarctica blooms in the Ross Sea, Antarctica. Nature 404, 595-598.

Gabric, A., Gregg, W., Najjar, R., Erickson, D., Matrai, P., 2001. Modeling the biogeochemical cycle of dimethylsulfide in the upper ocean: a review. Chemosphere-Global Change Science 3, 377-392.

Galí, M., Saló, V., Almeda, R., Calbet, A., Simó, R., 2011. Stimulation of gross dimethylsulfide (DMS) production by solar radiation. Geophysical Research Letters 38, L15612.

Galí, M., Simó, R., 2010. Occurrence and cycling of dimethylated sulfur compounds in the Arctic during summer receding of the ice edge. Marine Chemistry 122 , 105-117.

Gambaro, A., Moret, I., Piazza, R., Andreoli, C., Rin, E.D., Capodaglio, G., Barbante, C., Cescon, P., 2004. Temporal evolution of DMS and DMSP in Antarctic coastal sea water. International Journal of Environmental Analytical Chemistry 84, 401-412.

Holm-Hansen, O., Lorenzen, C.J., Holmes, R.W., Strickland, J.D.H., 1965. Fluorometric determination of chlorophyll. Journal du Conseil 30, 3-15.

Holton, J.R., 1992. An Introduction to Dynamic Meteorology, 3rd ed. International Geophysics Series. Academic Press, San Diego, New York.

Howard, E.C., Henriksen, J.R., Buchan, A., Reisch, C.R., Bürgmann, H., Welsh, R., Ye, W., González, J.M., Mace, K., Joye, S.B., Kiene, R.P., Whitman, W.B., Moran, M.A., 2006. Bacterial taxa that limit sulfur flux from the ocean. Science 314 649-652.

Jones, G., Fortescue, D., King, S., Williams, G., Wright, S., 2010. Dimethylsulphide and dimethylsulphoniopropionate in the South-West Indian Ocean sector of East Antarctica from $30^{\circ}$ to $80^{\circ}$ E during BROKE-West. Deep-Sea Research II 57 863-876.
Kettle, A.J., Andreae, M.O., 2000. Flux of dimethylsulfide from the oceans: a comparison of updated data sets and flux models. Journal of Geophysical Research 105, 793-808.

Kettle, A.J., Andreae, M.O., Amouroux, D., Andreae, T.W., Bates, T., Berresheim, H., Bingemer, H., Boniforti, R., Curran, M.A.J., DiTullio, G.R., et al., 1999. A global database of sea surface dimethylsulfide (DMS) measurements and a procedure to predict sea surface DMS as a function of latitude, longitude, and month. Global Biogeochemical Cycles 13, 399-444

Kieber, D.J., Jiao, J., Kiene, R.P., Bates, T.S., 1996. Impact of dimethylsulfide photochemistry on methyl sulfur cycling in the equatorial Pacific Ocean. Journal of Geophysical Research 101, 3715-3722.

Kieber, D.J., Toole, D.A., Jankowski, J.J., Kiene, R.P., Westby, G.R., del Valle, D.A., Slezak, D., 2007. Chemical "light meters" for photochemical and photobiological studies. Aquatic Sciences 69, 360-376.

Kiene, R.P., Bates, T.S., 1990. Biological removal of dimethyl sulphide from sea water. Nature 345, 702-704.

Kiene, R.P., Kieber, D.J., Slezak, D., Toole, D.A del Valle, D.A.,Bisgrove, J., Brinkley, J., Rellinger, A., 2007. Distribution and cycling of dimethylsulfide, dimethylsulfoniopropionate, and dimethylsulfoxide during spring and early summer in the Southern Ocean south of New Zealand. Aquatic Sciences 69, 305-319.

Kiene, R.P., Linn, L.J., 2000. The fate of dissolved dimethylsulfoniopropionate (DMSP) in seawater: tracer studies using 35S-DMSP. Geochimica et Cosmochimica Acta 64, 2797-2810.

Kiene, R.P. Service, S.K. 1991. Decomposition of dissolved DMSP and DMS in estuarine waters: dependence on temperature and substrate concentration. Marine Ecology Progress Series 76, 1-11.

Kirst, G.O., Thiel, C., Wolff, H., Nothnagel, J., Wanzek, M., Ulmke, R., 1991. Dimethylsulfoniopropionate (DMSP) in icealgae and its possible biological role. Marine Chemistry 35, 381-388.

Klinck, J.M., Hofmann, E.E., Beardsley, R.C., Salihoglu, B., Howard, S., 2004. Watermass properties and circulation on the west Antarctic Peninsula Continental Shelf in Austral Fall and Winter 2001. Deep-Sea Research II 51, 1925-1946.

Kloster, S., Feichter, J., Maier-Reimer, E., Six, K.D., Stier, P., Wetzel, P., 2006. DMS cycle in the marine ocean-atmosphere system - a global model study. Biogeosciences 3, 29-51.

Knap, A.H., Michaels, A., Close, A., Ducklow, H., Dickson, A.G., 1994. Protocols for the Joint Global Ocean Flux Study (JGOFS) Core Measurements. JGOFS, Reprint of the IOC Manuals and Guides (No. 29). UNESCO, Paris.

Kozlowski, W.A., Deutschman, D., Garibotti, I., Trees, C., Vernet, M., 2011. An evaluation of the application of CHEMTAX to Antarctic coastal pigment data. Deep-Sea Research I 58, 350-364.

Lana, A., Bell, T.G., Simó, R., Vallina, S.M., Ballabrera-Poy, J., Kettle, A.J., Dachs, J., Bopp, L., Saltzman, E.S., Stefels, J., Johnson, J.E., List, P.S., 2011. An updated climatology of surface dimethlysulfide concentrations and emission fluxes in the global ocean. Global Biogeochemical Cycles 25, GB1004.

Large, W.G., McWilliams, J.C., Doney, S.C., 1994. Oceanic vertical mixing: a review and a model with a nonlocal boundary layer parameterization. Reviews of Geophysics 32, 363-403.

Leck, C., Bigg, E.K., 2010. New particle formation of marine biological origin Aerosol Science and Technology 44, 570-577.

Liss, P.S., Merlivat, L., 1986. Air-sea gas exchange rates: introduction and synthesis. In: Buat-Menard, P. (Ed.), The Role of Air-sea Exchange in Geochemical Cycling. , D. Reidel, Dorderecht, Boston, pp. 113-127.

Nedwell, D.B., Shabbeer, M.T., Harrison, R.M., 1994. Dimethyl sulphide in North Sea waters and sediments. Estuarine, Coastal and Shelf Science 39, 209-217.

Nightingale, P.D., Malin, G., Law, C.S., Watson, A.J., Liss, P.S., Liddicoat, M.I., Boutin, J., Upstill-Goddard, R.C., 2000. In situ evaluation of air-sea gas exchange parameterizations using novel conservative and volatile tracers. Global Biogeochemical Cycles 14, 373-387.

Rodi, W., 1987. Examples of calculation methods for flow and mixing in stratified fluids. Journal of Geophysical Research 92, 5305-5328.

Saltzman, E.S., King, D.B., Holmen, K., Leck, C., 1993. Experimental determination of the diffusion coefficient of dimethylsulfide in water. Journal of Geophysical Research 98, 16481-16516.

Seymour, J.R., Simó, R., Ahmed, T., Stocker, R., 2010. Chemoattraction to dimethylsulfoniopropionate throughout the marine microbial food web. Science 329 , 342-345.

Simó, R., 2001. Production of atmospheric sulfur by oceanic plankton: biogeochemical, ecological and evolutionary links. Trends in Ecology and Evolution 16, 287-294.

Simó, R., Pedrós-Alió, C., 1999. Short-term variability in the open ocean cycle of dimethylsulfide. Global Biogeochemical Cycles 13, 1173-1181.

Simó, R., Vila-Costa, M., Alonso-Sáez, L., Cardelús, C., Guadayol, Ò., VázquezDomínguez, E., Gasol, J.M., 2009. Annual DMSP contribution to S and C fluxes through phytoplankton and bacterioplankton in a NW Mediterranean coasta site. Aquatic Microbial Ecology 57, 43-55.

Slezak, D., Kiene, R.P., Toole, D.A., Simó, R., Kieber, D.J., 2007. Effects of solar radiation on the fate of dissolved DMSP and conversion to DMS in seawater. Aquatic Sciences 69, 377-393.

Smith, D.A., Hofmann, E.E., Klinck, J.M., Lascara, C.M., 1999. Hydrography and circulation of the west Antarctic Peninsula continental shelf. Deep-Sea Research I 46, 925-950.

Spiese, C., Kieber, D.J., Nomura, C.T., Kiene, R.P., 2009. Reduction of dimethylsulfoxide to dimethylsulfide by marine phytoplankton. Limnology and Oceanography $54,560-570$.

Squires, G.L., 2001. Practical Physics. Cambridge University Press, New York.

Stefels, J., 2000. Physiological aspects of the production and conversion of DMSP in marine algae and higher plants. Journal of Sea Research 43, 183-197. 
Stefels, J., Steinke, M., Turner, S., Malin, G., Belviso, S., 2007. Environmental constraints on the production and removal of the climatically active gas dimethylsulphide (DMS) and implications for ecosystem modelling. Biogeochemistry $83,245-275$.

Sunda, W., Kieber, D., Kiene, R., Huntsman, S., 2002. An antioxidant function for DMSP and DMS in marine algae. Nature 418, 317-320.

Toole, D.A., Kieber, D.J., Kiene, R.P., Siegel, D.A., Nelson, N.B., 2003. Photolysis and the dimethylsulfide (DMS) summer paradox in the Sargasso Sea. Limnology and Oceanography $48,1088-1100$.

Toole, D.A., Kieber, D.J., Kiene, R.P., White, E.M., Bisgrove, J., del Valle, D.A., Slezak, D., 2004. High dimethylsulfide photolysis rates in nitrate-rich Antarctic waters. Geophysical Research Letters 31, L11307.

Toole, D.A., Siegel, D.A., 2004. Light-driven cycling of dimethylsulfide (DMS) in the Sargasso Sea: closing the loop. Geophysical Research Letters 31, L09308.

Toole, D.A., Slezak, D., Kiene, R.P., Kieber, D.J., Siegel, D.A., 2006. Effects of solar radiation on dimethylsulfide cycling in the western Atlantic Ocean. Deep-Sea Research I 53, 136-153.

Vairavamurthy, A., Andreae, M.O., Iverson, R.L., 1985. Biosynthesis of dimethylsulfide and dimethylpropiothetin by Hymenomonas carterae in relation to sulfur source and salinity variations. Limnology and Oceanography 30, 59-70. del Valle, D.A., Kieber, D.J., Toole, D.A., Brinkley, J., Kiene, R.P., 2009. Biological consumption of dimethylsulfide(DMS) and its importance in DMS dynamics in the Ross Sea, Antarctica. Limnology and Oceanography 54, 785-798.

del Valle, D.A., Slezak, D., Smith, C.M., Rellinger, A.N., Kieber, D.J., Kiene, R.P., 2010. Effect of acidification on preservation of DMSP in seawater and phytoplankton cultures: evidence for rapid loss and cleavage of DMSP in samples containing Phaeocystis sp. Marine Chemistry 124, 57-67.

Vallina, S.M., Simó, R., Gassó, S., 2006. What controls CCN seasonality in the Southern Ocean? A statistical analysis based on satellite-derived chlorophyll and $\mathrm{CCN}$ and model-estimated $\mathrm{OH}$ radical and rainfall. Global Biogeochemical Cycles 20, GB1014.

Vila-Costa, M., Kiene, R.P., Simó, R., 2008. Seasonal variability of the dynamics of dimethylated sulfur compounds in a coastal northwest Mediterranean site. Limnology and Oceanography 53, 198-211.

Vlahos, P., Monahan, E.C., 2009. A generalized model for the air-sea transfer of dimethyl sulfide at high wind speeds. Geophysical Research Letters 36, L21605.

Wanninkhof, R., 1992. Relationship between wind speed and gas exchange. Journal of Geophysical Research 97, 7373-7382. 